\title{
Modifiers of Liver-Related Manifestation in the Course of NAFLD
}

Patrik Nasr, J ulia Blomdahl, Stergios Kechagias and Mattias Ekstedt

The self-archived postprint version of this journal article is available at Linköping University Institutional Repository (DiVA):

http:// urn.kb.se/ resolve?urn=urn:nbn:se:liu:diva-165978

N.B.: When citing this work, cite the original publication.

Nasr, P., Blomdahl, J., Kechagias, S., Ekstedt, M., (2020), Modifiers of Liver-Related Manifestation in the Course of NAFLD, Current pharmaceutical design, 26(10), 1062-1078.

https:/ / doi.org/ 10.2174/ 1381612826666200310142803

Original publication available at:

https:// doi.org/ 10.2174/1381612826666200310142803

Copyright: Bentham Science Publishers

http:// www.benthamscience.com/ 


\title{
Modifiers of liver-related manifestation in the course of
}

\section{NAFLD}

Patrik Nasr $^{1}$, Julia Blomdahl ${ }^{1}$, Stergios Kechagias ${ }^{1^{*}}$, Mattias Ekstedt ${ }^{{ }^{*}}$

patrik.nasr@liu.se, stergios.kechagias@liu.se, mattias.ekstedt@liu.se,

\author{
*These authors contributed equally \\ ${ }^{1}$ Department of Health, Medicine and Caring Sciences, Linköping University, Linköping, Sweden
}

Potential competing interests: None.

Keywords: End-stage liver disease, HCC, Fibrosis, Alcohol, Fibrosis progression

List of abbreviations: AAT, alpha-1 antitrypsin; AATD, AAT deficiency; ARLD, alcohol related liver disease; AUDIT, alcohol use disorder identification test; BMI, body mass index; CDT, carbohydrate deficient transferrin; CI, confidence interval; CK, cytokeratin; CVD, cardiovascular disease; FLIP, fatty liver inhibition of progression; GWAS, genome-wide association studies; HC, hepatocellular; HCC, hepatocellular carcinoma; HFE-gene, human homeostatic iron regulator gene; HSD17B13, 17ß-hydroxysteroid dehydrogenase 13; aHR, adjusted hazard ratio; MARC1, mitochondrial amidoxime-reducing component 1; MBOAT7, membrane bound O-acyltransferase domain-containing 7; MRI-PDFF, magnetic resonance imaging - proton density fat fraction; MRS, magnetic resonance spectroscopy; NAFL, nonalcoholic fatty liver; NAFLD, non-alcoholic fatty liver disease; NAS, NAFLD activity score; NASH, non-alcoholic steatohepatitis; aOR, adjusted hazard ratio, PEth, phosphatidylethanol; Pi, proteinase inhibitor; PNPLA3, patatin-like phospholipase domain-containing 3; RES, reticuloendothelial system; SAF, steatosis, activity, fibrosis; SERPINA1, serine proteinase inhibitor 1; SNP, single-nucleotide polymorphism; T2DM, type 2 diabetes mellitus; TM6SF2, 
transmembrane 6 superfamily 2; TUNEL, terminal deoxynucleotidyl transferase dUTP nick end labeling; ULN, upper limit of normal.

Contact information: Mattias Ekstedt, Department of Gastroenterology and Hepatology, University Hospital, SE-581 85 Linköping, Sweden

Disclosures: Nothing to disclose

Writing Assistance: None.

Guarantor of article: Mattias Ekstedt 


\section{Introduction}

Hepatic steatosis was once considered an innocent bystander of minimal importance for clinicians and patients. Today, the progressive potential of non-alcoholic fatty liver disease (NAFLD) is indisputable, and NAFLD is rising as a major indication for liver transplant.[1, 2] The incidence of NAFLD mirrors the global epidemic of obesity worldwide.[3] The global prevalence of NAFLD is estimated to 25\%, with the highest prevalence in the Middle East and South America, and the lowest prevalence in Africa.[4]

NAFLD entails a spectrum of histological features that ranges from non-alcoholic fatty liver (NAFL) to non-alcoholic steatohepatitis (NASH) with or without fibrosis.[5, 6] There is a strong association between the severity of NAFLD and the components of the metabolic syndrome.[7-9] NAFLD is also independently associated with cardiovascular disease and type 2 diabetes mellitus (T2DM).[10-13]

With a prevalence ranging between $20-33 \%$ in most countries, NAFLD will become a significant health care issue for patients and health care systems.[4, 14] Luckily, only a minority of NAFLD-patients will progress to cirrhosis with development of decompensation and liver related death.[15] NAFLD is a dynamic disease state with considerable fluctuation (i.e. progression and regression) of inflammation and fibrosis, often described as a seesaw effect.[16-18] Particularly, the inflammatory grade, i.e. lobular inflammation and ballooning, is highly dynamic, partly attributed to lifestyle factors that are difficult to completely account and control for in clinical trials. These include weight change, dietary composition and alcohol consumption. It is also important to remember that lobular inflammation and ballooning have high inter- and intraobserver variability with significant sampling variability.[19-26] NASH, i.e. the presence of steatosis, lobular inflammation and ballooning,[27, 28] is regarded as the 
progressive disease state, as NASH-patients have higher fibrosis stage compared to NAFLpatients and higher all-cause and liver-related mortality.[29, 30]

Fibrosis stage is, not surprisingly, a strong predictor of outcome in patients with NAFLD.[3133] Therefore, patients with high risk of fibrosis progression are the ones that should be targeted with lifestyle and pharmacological interventions.[34-36] This review will focus on factors that has been shown to affect fibrosis progression and the development of liver cirrhosis, decompensation and liver-related mortality in NAFLD-patients.

\section{Metabolic Syndrome}

\subsection{Type 2 Diabetes Mellitus and Insulin Resistance}

Since 1980 the age-standardized prevalence of T2DM in adults has doubled in men (from 4.3\% to $9.0 \%$ ) and increased in women (from 5.0\% to 7.9\%).[37] NAFLD is highly intertwined with T2DM, showing a bidirectional interaction.[9, 30, 38-40] The prevalence of T2DM in NAFLDpatients ranges from $45 \%$ to $75 \%$ in hospital based studies and from $30 \%$ to $60 \%$ in population based studies.[41] Furthermore, the overall prevalence of NAFLD in individuals with T2DM is estimated at 55\%.[42] Nonetheless, whether NAFLD precedes or succeeds T2DM is still unclear.[43, 44]

In a systematic review and meta-analysis by Bellestri et al, patients with NAFLD had a twofold increase in the risk of incident T2DM.[45] Similarly, Chen et al showed that NAFLD patients (diagnosed with ultrasonography) had more than a twofold increase for T2DM (aHR 2.08, 95\%CI 1.93-2.33 for men and aHR 2.65, 2.43-2.88 for women), in a study with 132,377 adults, followed over a period of 6 years.[46]

There are few papers studying the relationship between patients with biopsy proven NAFLD and the risk of developing T2DM. In a seminal paper by Ekstedt et al, 129 well defined biopsy- 
proven NAFLD patients were included and followed prospectively and longitdunally.[47] At inclusion 11 out of 129 patients (8.5\%) had T2DM. After a mean follow-up time of 13.7 years, 69 out of 129 patients (53\%) had T2DM or impaired glucose tolerance. In an extended followup of the same cohort, 71 out of 129 had T2DM or impaired glucose tolerance (55\%) after a mean follow-up of 19.8 years.[48] Similarly, McPherson et al, showed an increase in T2DM in 108 patients with biopsy-proven NAFLD.[49] At baseline 48\% had T2DM, which increased to $65 \%$ after a median follow-up of 6.6 years.

To date there are 14 dual biopsy studies in patients with NAFLD, including 740 individuals with an overall T2DM prevalence of approximately 43\% (Table 1).[47, 49-61] In these studies, none show that T2DM predicts fibrosis progression, however, Adams et al, showed that T2DM was a predictor of fibrosis progression rate. Nevertheless, patients with NAFLD and concomitant T2DM portend an increased risk of mortality[33, 62] and an increased risk of liver related morbidity.[62] Also, patients with T2DM seem to have increased mortality in the presence of concomitant NAFLD.[63]

In long-term follow-up studies of patients with biopsy-proven NAFLD the majority of studies have not shown T2DM to be a significant risk factor for liver-related outcomes. However, in a retrospective study with 148 patients undergoing transjugular liver biopsy, diabetes was more prevalent in patients with liver-related clinical outcomes (including all-cause mortality) compared to patients without diagnosis of T2DM (62.5\% vs. 27.4\%).[64] Moreover, in a recent study by Vilar-Gomez et al, T2DM was proven to be a robust negative predictor of transplantation free survival (HR 3.33, 95\%CI 1.69-6.54) and liver-related outcome (sHR 2.82, 95\%CI 1.54-5.15 for decompensation and sHR 4.72, 95\%CI 2.13-10.45 for hepatocellular carcinoma [HCC]).[65] 
An estimated $8.4 \%$ of all deaths are attributed to T2DM with an approximate reduction in lifetime of about 6 years compared to non-T2DM individuals.[66, 67] T2DM, and especially insulin-dependent T2DM, increases death of all causes.[68-70] In a study by the Emerging Risk Factor Collaboration group, the adjusted hazard ratio among patients with T2DM compared with persons without diabetes was 1.80 (95\%CI 1.71-1.90) for death from any cause and 1.25 (95\%CI 1.19-1.31) for death from cancer - with liver cancer (e.g. HCC) having the highest risk (aHR 2.16, 95\%CI 1.62-2.88).[67] Moreover, in T2DM-patients that died from other causes other than cancer and nonvascular causes, the risk of death secondary to liver disease was 2.28 (95\%CI 1.90-2.74). These data were corroborated in a recent study by Campbell et al, were T2DM-patients had more than a twofold relative risk increase in dying of liver related causes.[71]

The relationship between T2DM and HCC is well established.[72-74] In an important article from the United Kingdom, Dyson et al showed an increase in HCC mortality from the year 2000 to 2010 (1.8-fold increase, rising from 2.0 to 3.7 per 100,000), mainly attributing to NAFLD - now the most common chronic liver disease associated with HCC (35\% of all cases).[75] In 2004, El-Serag et al, showed that patients with T2DM, without viral hepatitis infection or alcohol overconsumption, had a twofold increase of developing HCC compared to patients without diabetes (aHR 2.13, 95\%CI 1.99-2.28).[76] Moreover, T2DM seems to be an independent risk factor for developing HCC, mainly attributed to NAFLD.[76, 77] Similarly, a more than twofold increase in the risk of developing HCC amongst patients with T2DM have been observed in two meta-analyses.[78, 79]

Before the diagnosis of NAFLD was broadly accepted, early case-control studies showed cryptogenic cirrhosis to be related with the development of HCC.[80-82] Similarly, NAFLD is related to HCC. In most studies, there is an approximately twofold risk of developing HCC in patients with T2DM or NAFLD. However, because of the strong association between NAFLD 
and T2DM, it is hard to know if the increased risk of HCC is secondary to T2DM or its hepatic manifestation (i.e. NAFLD). Therefore, more studies are needed, depicting whether NAFLD patients with T2DM have an increased risk of HCC compared to NAFLD patients without T2DM.

\subsection{Overweight, Obesity and Weight Change}

Individuals with a body mass index (BMI) $\geq 30 \mathrm{~kg} / \mathrm{m}^{2}$ (i.e. obesity) have increased sixfold since 1980, affecting over 600 million individuals in 2016, with an additional 1.3 billion overweight (BMI 25.0-29.9 kg/m²) individuals.[3] Overweight has previously been seen as a culprit in allcause mortality, especially in death from cardiovascular disease and malignancy. However, there is an ongoing debate on the relationship between overweight and mortality.[83] Nonetheless, there is a clear consensus on obesity and increased all-cause mortality.[84-86]

The prevalence of NAFLD is highly related to body weight, with increasing prevalence in overweight and obese individuals. However, it is important to acknowledge that NAFLD is not uncommon in lean individuals.[87] In a recent study by Lazo et al, the prevalence of NAFLD increased exponentially in individuals with higher BMI; with a prevalence of 57\% in men and $44 \%$ in women with a BMI $>35 \mathrm{~kg} / \mathrm{m}^{2}$.[88] However, this estimated prevalence is probably an underestimation, since all patients were diagnosed with ultrasonography - a method with low sensitivity in patients with low grade steatosis. The gold standard for diagnosing NAFLD is magnetic resonance spectroscopy (MRS),[89, 90] where the commonly used cut-off of $5 \%$ or $5.56 \%$ is applied.[91, 92] Using the cut-off of 5.56\%, the prevalence of NAFLD among 2,287 individuals included in the Dallas Heart Study was 31\%.[93] However, the cut-off of 5\% is questioned[94-96] with some studies recommending a lower cut-off of 3\%.[97, 98] 
There exists a high correlation between overweight/obesity and NAFLD. However, the causal relationship between the two is not clear.[99, 100] In the Coronary Artery Risk Development in Young Adults study, future development of NAFLD was related to weight gain during young adulthood.[101] Furthermore, weight loss, either by lifestyle intervention or bariatric surgery, seem to resolve NAFLD (and insulin resistance).[102-106] Moreover, in a recent study by Vilar-Gomez et al, 239 biopsy-proven NAFLD patients underwent lifestyle changes to reduce their body weight.[107] Patients were followed for 52 weeks, after which a repeat liver biopsy was performed. Weight loss $>5 \%$ showed a significant reduction in steatosis, inflammation, ballooning and fibrosis. The resolution of these histological parameters increased in patients with higher percentage weight reduction.

Obesity and visceral adiposity seems to predict the development of severe liver disease in the general population.[108-110] In a prospective study by Calle et al, an increased risk of mortality from cancer showed a linear association with increasing BMI, in both men and women.[111] Moreover, they showed an exponential increase in the risk of liver cancer in male subjects for every 5 unit increase in BMI. Similar findings were reported by Hagström et al, where 1.2 million men enlisted for military conscription in Sweden, were followed for a mean period of 28.5 years.[112] At the end of follow-up, 5281 cases of severe liver disease and 251 cases of HCC were identified. Individuals who were overweight and obese had an increased hazard ratio for HCC of 1.68 (95\%CI 1.09-2.57) and 4.28 (95\%CI 2.25-8.15), respectively.

\section{Alcohol}

In the Western world, alcohol overconsumption is the leading cause of advanced decompensated liver disease.[113] Thus, a potentially important factor for the course of NAFLD is the impact of the quantity, pattern, and duration of alcohol consumption. Weekly alcohol consumption in excess of $210 \mathrm{~g}$ for men and $140 \mathrm{~g}$ for women exclude subjects from NAFLD research studies.[114] However, these arbitrary thresholds are based on levels above 
which the risk of cirrhosis is higher and has not been specifically shown to influence NAFLD.[115] On the other hand, the most common cause of mortality and morbidity in NAFLD patients is cardiovascular disease (CVD) [47, 116] and NAFLD and CVD share many common risk factors. There is evidence for beneficial effects of modest alcohol consumption on risk of metabolic syndrome and insulin resistance,[117] which are important components of the NAFLD disease process.

An important confounder when investigating the role of alcohol in the progression or improvement of NAFLD is the assessment of alcohol consumption. The recommended tool for excluding excessive alcohol consumption when diagnosing NAFLD is the Alcohol Use Disorders Identification Test (AUDIT), in which specific questions explore consumption, dependence, and alcohol related problems.[118, 119] However, people consuming alcohol may be prone to inaccurately report that they do not have a problem, particularly when meeting physicians evaluating their liver. This creates a need for more objective methods to investigate a person's drinking habits. Serum levels of the specific alcohol marker carbohydrate deficient transferrin (CDT) can be used when heavy drinkers are investigated but for social drinkers and risk drinkers CDT lacks adequate sensitivity.[120] Analysis of phosphatidylethanol (PEth) has emerged as a more sensitive and specific method[121] but has hitherto been used only in few NAFLD studies thus making it hard to assess its utility in the NAFLD setting.

Studies on effects of alcohol in NAFLD have evaluated four different aspects: 1) effects of alcohol on prevalence or incidence of NAFLD, 2) effects of alcohol on the severity of established NAFLD, 3) association of alcohol consumption with hepatocellular carcinoma in NAFLD, and 4) association of alcohol consumption with mortality in NAFLD patients.

A recent meta-analysis of mostly cross-sectional studies concluded that moderate alcohol consumption was associated with a 23\% reduction in the prevalence of fatty liver disease.[122] In a prospective Japanese study of subjects without liver disease at baseline drinking alcohol 
was associated with decreased incidence of fatty liver diagnosed by ultrasonography.[123] Moreover, moderate alcohol consumption did not induce hepatic steatosis in healthy individuals when hepatic triglyceride content was measured prospectively with proton magnetic resonance spectroscopy in a randomized study.[124]

The largest study assessing the second aspect was recently reported by Chang et al.[125] They studied the effect of moderate alcohol consumption on non-invasive liver fibrosis indices in 58,927 Korean adults with NAFLD and low fibrosis scores who were followed for a median of 8.3 years. They concluded that moderate alcohol consumption was significantly and independently associated with worsening of non-invasive markers of fibrosis. The rationale for the study is relevant, since fibrosis stage is the best predictor of future liver-related morbidity and overall mortality in NAFLD.[33, 126] Thus, their study may indicate that modest alcohol consumption is harmful in subjects with NAFLD. However, a major weakness of using noninvasive fibrosis markers is that, although they are excellent in ruling out significant fibrosis, their ability to confirm advanced fibrosis is limited when liver biopsy is used as the reference method. Thus, worsening of fibrosis indices does not necessarily imply that liver fibrosis has progressed during follow-up.

Liver biopsy is still considered the gold standard for assessing the severity of NAFLD. In a cross-sectional study of adult patients with biopsy-proven NAFLD, after exclusion of heavy and binge drinkers, modest alcohol consumption was associated with 34\% less hepatocellular ballooning and 44\% lower risk of liver fibrosis compared with nondrinkers.[127] Similar results were shown in a Swedish study of 120 NAFLD patients with biopsy-proven NAFLD in which a maximum of 13 drinks per week was associated with lower fibrosis stage.[128] However, increased levels of PEth in blood was associated with higher stages of fibrosis. This may indicate that more pronounced alcohol consumption, contrary to modest consumption, is harmful in NAFLD or that assessment of alcohol consumption through questionnaires is prone 
to error. In another histopathological study from Sweden,[129] 71 NAFLD patients were followed for an average of almost 14 years and it was shown that heavy episodic drinking was associated with increased risk of progression of fibrosis. Further evidence for a potentially harmful effect of moderate alcohol consumption on the progression of NAFLD comes from a recently published longitudinal study,[130] in which it was concluded that NAFLD patients with moderate alcohol consumption were less likely to experience spontaneous improvement in liver histology.

Currently, twelve studies have assessed the impact of alcohol on histopathology in NAFLD (Table 2). Robust conclusions cannot be drawn since study design varies and particularly since the definition of moderate alcohol consumption is not consistent. However, type of alcohol and pattern of consumption seem to affect the histopathological course of NAFLD. Generally, consumption of moderate amounts of alcohol $(<70 \mathrm{~g} / \mathrm{week})$ is associated with a lower rate of NASH and fibrosis, especially if wine is consumed in a non-binge pattern. However, this is not a consistent finding. In some studies, moderate alcohol consumption is associated with a more advanced histopathological stage. Binge drinking (occasional consumption of $>60$ g ethanol in males and $>48 \mathrm{~g}$ in females) may be harmful since it is associated with higher fibrosis stages.

There is increasing evidence to suggest an additive, or even a synergistic, effect between alcohol consumption and BMI for the development of HCC.[131] In a recent Japanese study of 301 patients with biopsy-proven NAFLD, patients with modest drinking had s significantly higher risk of developing HCC compared with nondrinkers.[132]

Results regarding the effect of alcohol consumption on survival in NAFLD patients have been conflicting.[123, 127] Recently, 4,568 subjects with NAFLD from the National Health and Nutrition Examination Survey were evaluated. Consumption of 7 g to 21 g alcohol per day decreased the risk of overall mortality by $41 \%$ compared with not drinking.[133] Since NAFLD patients are more likely to die from CVD than liver disease these results are in accordance with 
previous studies showing that modest alcohol consumption is associated with decreased risk of cardiovascular disease mortality.[134] However, a major weakness of the aforementioned study[133] is that the diagnosis of NAFLD was based on a biochemical model and not on imaging or histology.

In summary, most studies indicate that modest alcohol consumption is associated with decreased risk for development of fatty liver disease and moderate drinking may be associated with increased survival in NAFLD patients. Emerging evidence indicates an additive risk of BMI and alcohol for the development of HCC in NAFLD. There are conflicting results regarding the role of alcohol for fibrosis progression in established NAFLD. Further studies are needed before well founded advice can be given to NAFLD patients regarding modest alcohol consumption.

\section{Genetics}

\section{1 Genome-wide Association Studies}

The large differences in NAFLD prevalence between regions and ethnicity are multifactorial, but genetic factors are clearly one explanation for the variation observed. Genome-wide association studies (GWAS) have identified several gene loci associated with NAFLD. The non-synonymous chromosome 22 single-nucleotide polymorphism (SNP) in the patatin-like phospholipase domain-containing 3 (PNPLA3, rs738409 c.444 C>G, p.lle148Met) and the nonsynonymous chromosome 19 SNP in the transmembrane 6 superfamily 2 (TM6SF2) has repeatedly been associated with hepatic steatosis as well as inflammation and fibrosis.[135138] The development of NAFLD-related HCC has been associated with the PNPLA3 genotype.[139-141] Interestingly, recently gene loci such as the mitochondrial amidoxime- 
reducing component 1 (MARC1) and the 17ß-hydroxysteroid dehydrogenase 13 (HSD17B13) has shown to be protective against fatty liver and fibrosis.[142-144]

The gene locus rs641738 at the membrane bound O-acyltransferase domain-containing 7 (MBOAT7) has been associated with NAFLD,[145] but this association has recently been disputed.[146] There is a number of additional genes that is associated with NAFLD such as the LYPLAL1, GCKR and PP1R3B.[147, 148]

By studying the functional role of each gene associated with NAFLD has given many interesting openings to study the pathogenesis of the disease. Although, the era of personalized medicine is yet to start. Genetic testing for at least PNPLA3 and TM6SF2 will be important in future clinical trials.

\subsection{Hemochromatosis and Iron dysregulation}

Many patients with NAFLD have manifest iron dysregulation with 58\% having hyperferritinemia,[149] >34\% having stainable hepatic iron[150, 151] and several having mutations in the HFE gene.[151, 152]

The relationship between iron and NAFLD was first described by George et al, who showed that hepatic iron (Perl's stain or hepatic iron concentration) had the strongest association with fibrosis stage in 51 patients with NASH.[153] In a seminal article by Bugianesi et al, 167 patients with biopsy-proven NAFLD were evaluated.[154] Higher level of ferritin was associated with an increased risk of present higher fibrosis stage.

The relationship of serum ferritin with severity of NAFLD has been examined in several studies.[154-157] In a study by the NASH Clinical Research Network (CRN), 628 patients with biopsy proven NAFLD were included.[157] Patients with ferritin higher than 1.5 times and 2.5 times upper limit of normal had a 1.67 and 2.46-fold increased risk of advanced fibrosis. 
Moreover, Hagström et al showed that biopsy-proven NAFLD patients with higher levels of ferritin had a long-term increased risk of death.[158] Although the association between ferritin and advanced fibrosis has been corroborated by several study groups[156, 157, 159], the use of ferritin for predicting presence of advanced fibrosis in NAFLD is low (ferritin $>1.5 \mathrm{x}$ ULN: AUROC 0.56, 95\%CI $0.52-0.60$ ) with a sensitivity and specificity of $27 \%$ and $84 \%$, respectively.[159]

Early case studies of iron depletion through phlebotomy showed decreased insulin resistance,[160] improvement of steatosis grade,[161] and liver enzymes.[161, 162] However, in a phase 2 clinical trial[163] and a randomized controlled trial[164], phlebotomy had no effect on liver enzymes, hepatic fat (measured with MRI), insulin resistance or histological features of NAFLD. It is notable that the endpoint in these two studies was not fibrosis progression, decompensation or liver-related mortality.

In a study by Nelson et al, 849 biopsy-proven NAFLD patients were enrolled.[150] Approximately one third (34.5\%) had hepatic iron deposits, divided into a hepatocellular (HC) pattern (7.4\%), a reticuloendothelial system (RES) cell pattern (10.7\%) or mixed pattern (16.4\%). The pathogenic effect of iron deposit depended on the cellular location in the liver, where patients with RES iron-staining pattern were more likely to have features of any stage of fibrosis and advanced fibrosis, portal inflammation and ballooning compared to patients with HC iron-staining pattern. Furthermore, patients with RES iron deposits had an increased level of TUNEL positive cells (a marker of apoptosis) in the liver and increased levels of malondialdehyde (a marker of oxidative stress) as well as CK-18 (a marker of apoptosis) in serum. [165] Also, in an Italian study by Valenti et al, 587 biopsy-proven NAFLD patients were enrolled to investigate the effects of (serological and histological) iron and genetic hemochromatosis in NAFLD.[166] They reported that hepatocellular iron accumulation was associated with a higher risk of fibrosis stage $>1$ (aOR 1.7, 95\%CI 1.2-2.3) compared to patients 
without siderosis. Although, there was no significant association between presence of genetic hemochromatosis (or specific HFE-genotypes) and the severity of fibrosis, one third of patients with HFE-mutations had hepatocellular iron deposits.

Elevated ferritin is commonly seen in patients with NAFLD and could indicate more advanced disease. But, significant elevation of hepatic iron content in individuals without genetic predisposition is uncommon.[167] Phlebotomy of NAFLD patients with elevated ferritin is probably unnecessary in a clinical setting. Nevertheless, patients with increased stainable iron in liver biopsies could still benefit from iron depletion regarding fibrosis progression, which warrants further investigation.

\subsection{Alpa-1 Antitrypsin Deficiency}

Alpha-1 antitrypsin (AAT) is a serum protein produced predominantly in liver hepatocytes.[168] It is coded by the serine proteinase inhibitor, SERPINA1 gene (previously known as the protein inhibitor, or Pi locus), and variants of AAT mutations typically lead to misfolding of AAT in the endoplasmatic reticulum and decreased serum AAT concentrations, resulting in AAT deficiency (AATD).[168] Typically, sever forms of AATD results in low levels of AAT ( $15 \%$ of normal) and is a “common rare disease”, being the third most common genetic disorder leading to death globally.[168-170] There are more than 150 SERPINA1 alleles described, with the normal allele referred to as "M". However, the most frequent and well investigated diseases associated with SERPINA1 mutations are the "Z" and "S" alleles with the lung and the liver being the most commonly affected organs.[168]

AATD is most prevalent in Scandinavia and North America, and in a meta-analysis by Serres et al, the global prevalence for heterozygotic SERPINA1 mutations (PiMS and PiMZ) is 3.4\% and for that of homozygotic mutations (PiZZ, PiZS and PiSS) is 0.8\%.[171] The two largest population-based studies performed, investigating the prevalence of $\mathrm{Z}$ and $\mathrm{S}$ allele, were in 
newborn infants in Sweden and Oregon, USA, with a prevalence of 1:1639 and 1:5097, respectively.[172, 173]

While the presence of PiZZ genotype portend a high risk of future liver disease, the role of PiMZ in liver disease remains controversial.[174-177] In a study by Regev et al, 651 patients with known chronic liver disease, of whom $26 \%$ had NAFLD, were tested for AAT phenotypes.[178] Although they did not find any association between the heterozygous PiZ state of AATD and the presence of chronic liver disease, the presence of PiMZ was more common in NAFLD patients with decompensated liver disease. Similarly, approximately 20$30 \%$ of NAFLD patients awaiting liver transplant have the PiMZ phenotype.[176, 179]

In an important multi-center study by Strnad et al, 1148 patients with biopsy proven NAFLD and 2462 with biopsy proven alcohol related liver disease (ARLD) were enrolled, with both cohorts comprising cases with cirrhosis and controls.[180] In patient with NAFLD, $13.8 \%$ of patients with cirrhosis (9/68) had PiZ variant present, compared to $2.4 \%$ of those without any stage of fibrosis (9/362). The PiZ variant increased the risk of developing cirrhosis in patients with NAFLD (aOR 7.3, 95\%CI 2.2-24.8). Similarly, patients with cirrhosis secondary to ARLD had an increased prevalence of PiZ compared to controls with ARLD and no fibrosis (6.2\% vs. 2.2\%) and an increased risk of developing cirrhosis if carrying the PiZ variant (aOR 5.8, 95\%CI 2.9-11.7).

\section{Histology}

\subsection{Liver fibrosis}

Advanced fibrosis stage is the strongest independent predictor of all-cause mortality, liverrelated mortality and decompensation in NAFLD patients. In two recent systematic reviews and meta-analyses by Singh et al and Dulai et al, increased mortality was observed for every fibrosis stage.[31, 181] Singh et al showed that 33.6\% had fibrosis progression.[181] The overall annual 
fibrosis progression was found to be 0.07 stages for NAFL and 0.14 stages for NASH, corresponding to one stage of fibrosis progression over a median of 14.3 years and 7.1 years for NAFL and NASH, respectively.

There are 14 studies with paired biopsies in NAFLD-patients, including in total 740 patients with a median follow-up time between biopsies ranging from 2 to 13.8 years (Table 1).[47, 4961] In 10 of the studies, including 416 patients, fibrosis stage at baseline and follow-up are present.[47, 49, 50, 52-54, 56-59] Equal to the meta-analysis by Singh et al[181], 37\% show fibrosis progression (153/416) and $12 \%$ show progression from low stage fibrosis (F0-F2) to advanced fibrosis (F3-F4) (Table 1). However, with an alternating definition of NASH over time, comparisons are difficult to make in between studies. Nonetheless, in the present serial biopsy studies, few parameters predict fibrosis progression. Interestingly, presence of NASH or NAS at baseline does not correlate with fibrosis progression in these studies.

In an interesting article by Sanyal et al, 475 NAFLD-patients from the Simtuzumab trials, with NASH and bridging fibrosis or compensated cirrhosis, were followed for 96 weeks with some undergoing repeat liver biopsy.[61] Albeit fibrosis stage (according to Ishak) did not predict fibrosis progression from bridging to cirrhosis or from cirrhosis to liver-related clinical events, serum fibrosis markers and hepatic collagen content (per 5\% increase) did. The importance of histological fibrosis[31-33, 182] and biochemical fibrosis markers[183, 184] in predicting disease progression is repeatedly underlined. However, not all patients with fibrosis stage 3 progress to cirrhosis or end-stage liver disease. Given the significant variability and sampling error in utilizing liver biopsy, it is difficult to know if the relationship between fibrosis stage/hepatic collagen content/fibrosis biomarkers with fibrosis progression is a true association or merely a misclassification of baseline fibrosis stage.

\subsection{Non-Alcoholic Steatohepatitis}


Patients with NASH have increased mortality as shown in a previous meta-analysis by Musso et al where subjects with NASH had an almost two-fold increase in overall mortality and sixfold increase in liver-related mortality.[29] There is a strong association between NASH and fibrosis making it hard to differentiate between the effect of NASH, per se, on prognosis.

In the landmark paper by Brunt et al they characterized the histopathological hallmarks of NASH. It unified the lesions of steatosis and inflammation into a grade (0-3; ranging from none to mild, moderate and severe) and those of fibrosis, into a stage (ranging from 0-4).[185] Although this scoring system was appealing, it was developed for NASH and did not encompass the entire spectrum of NAFLD. Therefore, a multicenter cooperative named NASH Clinical Research Network (NASH-CRN) was formed.[186] The NASH-CRN developed a scoring protocol to include the entire spectrum of NAFLD.[27] The developed scoring system was coined NAFLD Activity Score (NAS). In NAS the unweighted sum of grades of steatosis, lobular inflammation, and hepatocellular ballooning presented the severity of NAFLD. Absence of NASH was defined as NAS $\leq 2$, "borderline NASH" as a NAS of 3 or 4 and definite NASH as NAS $\geq 5$. However, in that study, the authors clearly stated that NAS is not intended to replace the pathologist's diagnostic determination of NASH. In 2011, Younossi et al, studied

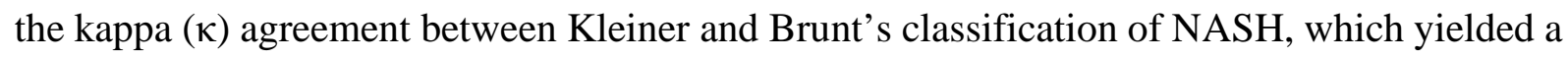
slight agreement $(\kappa=0.178)$.[187] Nonetheless, NAS is recommended to be used to define, quantify, and show progressions or regression of disease in clinical trials.[188]

In 2014, a new score named SAF (Steatosis, Activity, Fibrosis) was developed with a very good interobserver agreement for NASH $(\kappa=0.80)$.[28] In SAF score, steatosis and fibrosis are defined similarly to that of NAS, but with disease activity defined as the sum of ballooning and inflammation. The SAF score classifies NAFLD-patients as having mild (activity $<2$ and fibrosis $<2$ ) or significant (activity $>2$ or fibrosis $>2$ ) disease severity. In the same study, the Fatty Liver Inhibition of Progression (FLIP) algorithm was presented. With the FLIP algorithm, 
all NAFLD-patients with $\geq 1$ point in steatosis, ballooning and lobular inflammation each, are defined as having NASH. The FLIP algorithm differs from NAS so as when a NAFLD-patient with steatosis grade 3 and lobular inflammation grade 2 (NAS=5) is evaluated according to NAS - the definition of definite NASH is fulfilled. However, when evaluated according to the FLIP-algorithm, the same patient would be defined as "not-NASH”, though the FLIP-algorithm depends on inflammation and ballooning (except the main trait of steatosis) for the definition of NASH.

Recently, two articles, by Ekstedt et al and Angulo et al, showed that liver fibrosis, and no other histological features predicted disease specific and all-cause mortality in NAFLD-patients.[33, 126] The impact of NAS, did not have any effect on disease specific or all-cause mortality when adjusting for fibrosis. However, Ekstedt et al, showed that patients with NAS 5-8 and fibrosis stage 0-2 had a risk of developing HCC (HR 15.7, 95\%CI 4.1-59.9), but no increased risk of overall mortality (HR 1.41, 95\%CI 0.97-2.06).[126] SAF was recently evaluated in a Scandinavian study including 139 biopsy proven NAFLD-patients, with a follow-up of 25.3 years. After adjusting for fibrosis, SAF score did not predict all-cause mortality.[189]

The mechanisms driving fibrosis progression in NAFLD are multifactorial[190] with inflammation being the catalyst driving activation of stellate cells and matrix turnover and deposition.[191] The high inflammatory disease state in NAFLD is commonly defined as NASH according to NAS, SAF or FLIP. The idea that inflammation surpasses fibrosis in NAFLD is not contested. However, the notion that the presence of NASH correlates with presence of fibrosis does not mean that NASH equals the prediction of fibrosis progression. To date, there is no objective evidence that the presence of NASH at baseline, by any of the mentioned definitions, correlate with progression of fibrosis. And therefore, resolution of NASH is not likely to be synonymous with regression of fibrosis. Hence, caution should be 
taken when NASH is used as a surrogate for disease progression in observational and pharmacological trials.

\subsection{Ballooning Degeneration}

Ballooning degeneration is a form of hepatocyte apoptosis, histologically resulting in hepatocyte swelling, nuclei shrinkage and fragmentation. In a meta-analysis by Argo et al, lobular, portal or necroinflammatory (i.e. ballooning degeneration) inflammation predicted development of advanced fibrosis.[193] Moreover, Singh et al showed a more rapid fibrosis progression rate in patients with NASH compared to NAFL.[181] Also, Angulo et al, showed that NASH, defined by NAS, did not associate with long term outcomes in NAFLD when adjusting for fibrosis. However, patients with portal inflammation and ballooning degeneration showed an increased risk of end-stage liver disease.[33] Furthermore, a non-significant trend of ballooning degeneration as a predictor of fibrosis progression was seen in the study by McPherson et al ( $\mathrm{p}=0.08)$.[49] This was later corroborated by Sanyal et al in the Simtuzumab trials study, where baseline levels of severe ballooning degeneration (grade 2 vs. 0) were associated with disease progression (HR 4.83, 95\%CI 1.45-16.07).[61]

\subsection{Steatosis Grade}

In the presence of hepatic steatosis (grade $\geq 1$ ) and absence of lobular inflammation, ballooning and fibrosis, the term isolated steatosis is used. However, when isolated steatosis is accompanied by inflammation, the term non-alcoholic fatty liver (NAFL) is used.

Isolated steatosis is considered a benign condition and therefore few studies have focused on the natural history of this entity. In a serial biopsy study by Teli et al from 1995, 12 patients with isolated steatosis were included and followed for a median of 10.3 years.[52] Only one patient progressed, and did so from F0 to F1. Moreover, in a British serial biopsy study by 
McPherson et al, 17 were diagnosed with isolated steatosis of whom 4 had fibrosis progression.[49]

Further, recent studies have demonstrated fibrosis progression in a significant proportion of NAFL-patients.[49, 59, 60] In a prospective study by Wong et al, 29 patients with repeat liver biopsies were diagnosed with NAFL.[59] After a follow-up of 3 years, 28\% showed fibrosis progression. Moreover, Pais et al presented fibrosis progression in 6 out of 25 patients (24\%).[60] And in the study by McPherson et al, 10 out of 27 patients (37\%) showed fibrosis progression.[49]

In an abstract by McPherson, 321 NAFLD-patients with serial biopsies were followed for 4.1 years.[194] Out of the 321 patients, 35\% showed evidence of fibrosis progression, with no difference between NASH and NAFL. However, steatosis grade 2-3 was associated with fibrosis progression $(\mathrm{p}<0.001)$. Similarly, in a study by Ajmera et al, 95 patients with paired biopsies also underwent MRI-proton density fat fraction (PDFF).[194] Among the 38 patients without fibrosis (i.e. stage 0) at baseline, patients with higher liver fat (defined as MRI-PDFF $\geq 15.7 \%)$ had a higher rate, albeit nonsignificant, of fibrosis progression $(38.1 \%$ vs $11.8 \%$, $\mathrm{p}=0.067)$. Moreover, after adjusting for age, sex, ethnicity and BMI, patients with higher liver fat at baseline had an increased risk of fibrosis progression (aOR 6.67, 95\%CI 1.01-44.1). It is interesting that the amount of steatosis is associated with a progressive disease state in NAFLD. The majority of lipids in steatosis is triglycerides. The accumulation of triglycerides within the hepatocytes is considered protective with respect to cell toxicity.[195] So the association between steatosis grade and progressive disease is most likely driven by other lipid classes, such as free fatty acids (e.g. palmitic acid), cholesterol, lysophosphatidylcholine, and ceramides.[196] 


\section{Conclusion}

Disease progression in NAFLD (i.e. worsening of fibrosis stage, decompensation, liver-related and all-cause mortality) is highly related to traits of the metabolic syndrome, in particular T2DM/insulin resistance and overweight/obesity. Given the rising incidence of obesity and T2DM globally, we have only seen the beginning of the NAFLD epidemic. From the available evidence, 5-10\% of NAFLD-patients will develop cirrhosis and cirrhosis related complications.

Screening for NAFLD with liver enzymes and/or ultrasound in subjects with obesity or the metabolic syndrome is recommended in the EASL-EASD-EASO clinical practice guidelines for NAFLD.[114] This recommendation is a challenge for the health care system given the high prevalence of obesity and T2DM in the general population. A recent survey of the public health response to NAFLD in 29 European countries found a general lack of awareness and national policies.[197] On the other hand, a community-based screening and risk stratification pathway could be cost-effective.[198]

The most important, often underestimated, confounder in NAFLD research is unrecognized or underreported high alcohol consumption. Most NAFLD studies rely on patient self-estimation of alcohol consumption using AUDIT(-C). Although available, very few studies have used objective direct alcohol markers to validate self-estimated consumption. There is increasing evidence that there is an additive effect of metabolic risk factors and alcohol consumption in progressive NAFLD. It would be very interesting to see a retrospective analysis of objective direct alcohol markers' effect on treatment outcome and fibrosis progression in the available large, finalized treatment studies of NAFLD.

As we have outlined in this review, there are several modifiers of disease progression in NAFLD. Some are traditional metabolic risk factors - others are related to genes and lifestyle. Given that there is a strong strong association between NAFLD, metabolic profile, alcohol 
consumption and disease state it is difficult to determine what factors are driving progression or simply mirroring it.

In the clinical setting, the aforementioned risk factors, together with several accurate noninvasive techniques can be adequately utilized to find NAFLD patients with advanced fibrosis. However, in patients with less advanced disease state, it is difficult to identify those with rapid disease progression. These patients, with a more dismal disease trajectory, should be the ones targeted with surveillance and pharmacological intervention. 


\section{References}

[1] Wong RJ, Aguilar M, Cheung R, et al. Nonalcoholic steatohepatitis is the second leading etiology of liver disease among adults awaiting liver transplantation in the United States. Gastroenterology 2015; 148: 547-55.

[2] Pais R, Barritt AS, Calmus Y, et al. NAFLD and liver transplantation: Current burden and expected challenges. J Hepatol 2016; 65: 1245-57.

[3] Collaboration NCDRF. Worldwide trends in body-mass index, underweight, overweight, and obesity from 1975 to 2016: a pooled analysis of 2416 population-based measurement studies in 128.9 million children, adolescents, and adults. Lancet 2017; 390: 2627-42.

[4] Younossi ZM, Koenig AB, Abdelatif D, Fazel Y, Henry L, Wymer M. Global epidemiology of nonalcoholic fatty liver disease-Meta-analytic assessment of prevalence, incidence, and outcomes. Hepatology 2016; 64: 73-84.

[5] Matteoni CA, Younossi ZM, Gramlich T, Boparai N, Liu YC, McCullough AJ. Nonalcoholic fatty liver disease: a spectrum of clinical and pathological severity. Gastroenterology 1999; 116: 1413-9.

[6] Sanyal AJ, Association AG. AGA technical review on nonalcoholic fatty liver disease. Gastroenterology 2002; 123: 1705-25.

[7] Byrne CD, Targher G. NAFLD: A multisystem disease. Journal of Hepatology 2015; 62: S47-64.

[8] Byrne CD, Olufadi R, Bruce KD, Cagampang FR, Ahmed MH. Metabolic disturbances in nonalcoholic fatty liver disease. Clinical science 2009; 116: 539-64.

[9] Yki-Järvinen $\mathrm{H}$. Non-alcoholic fatty liver disease as a cause and a consequence of metabolic syndrome. Lancet Diabetes Endocrinol 2014; 2: 901-10.

[10] Wu S, Wu F, Ding Y, Hou J, Bi J, Zhang Z. Association of non-alcoholic fatty liver disease with major adverse cardiovascular events: A systematic review and meta-analysis. Sci Rep 2016; 6: 33386.

[11] Targher G, Day CP, Bonora E. Risk of cardiovascular disease in patients with nonalcoholic fatty liver disease. N Engl J Med 2010; 363: 1341-50.

[12] Targher G, Byrne CD, Lonardo A, Zoppini G, Barbui C. Non-alcoholic fatty liver disease and risk of incident cardiovascular disease: A meta-analysis. J Hepatol 2016; 65: 589-600.

[13] Fracanzani AL, Tiraboschi S, Pisano G, et al. Progression of carotid vascular damage and cardiovascular events in non-alcoholic fatty liver disease patients compared to the general population during 10 years of follow-up. Atherosclerosis 2016; 246: 208-13.

[14] Younossi ZM, Blissett D, Blissett R, et al. The economic and clinical burden of nonalcoholic fatty liver disease in the United States and Europe. Hepatology 2016; 64: 1577-86.

[15] Loomba R, Sanyal AJ. The global NAFLD epidemic. Nat Rev Gastroenterol Hepatol 2013; 10 : 686-90.

[16] Ratziu V, Sanyal A, Francque S, et al. Cenicriviroc treatment for adults with non-alcoholic steatohepatitis: Year 2 analysis of the Phase 2b CENTAUR study. Journal of Hepatology 2018; 68: S1-S2.

[17] Friedman SL, Ratziu V, Harrison SA, et al. A randomized, placebo-controlled trial of cenicriviroc for treatment of nonalcoholic steatohepatitis with fibrosis. Hepatology 2018; 67: 1754-67.

[18] Schuppan D, Surabattula R, Wang XY. Determinants of fibrosis progression and regression in NASH. Journal of Hepatology 2018; 68: 238-50.

[19] Ratziu V, Charlotte F, Heurtier A, et al. Sampling variability of liver biopsy in nonalcoholic fatty liver disease. Gastroenterology 2005; 128: 1898-906.

[20] Vuppalanchi R, Ünalp A, Van Natta ML, et al. Effects of Liver Biopsy Sample Length and Number of Readings on Sampling Variability in Nonalcoholic Fatty Liver Disease. Clinical Gastroenterology and Hepatology 2009; 7: 481-6. 
[21] Arun J, Jhala N, Lazenby AJ, Clements R, Abrams GA. Influence of Liver Biopsy Heterogeneity and Diagnosis of Nonalcoholic Steatohepatitis in Subjects Undergoing Gastric Bypass. Obesity Surgery 2007; 17: 155-61.

[22] Younossi ZM, Gramlich T, Liu YC, et al. Nonalcoholic fatty liver disease: assessment of variability in pathologic interpretations. Mod Pathol 1998; 11: 560-5.

[23] Larson SP, Bowers SP, Palekar NA, Ward JA, Pulcini JP, Harrison SA. Histopathologic Variability Between the Right and Left Lobes of the Liver in Morbidly Obese Patients Undergoing Roux-en-Y Bypass. Clinical Gastroenterology and Hepatology 2007; 5: 1329-32.

[24] Merriman RB, Ferrell LD, Patti MG, et al. Correlation of paired liver biopsies in morbidly obese patients with suspected nonalcoholic fatty liver disease. Hepatology 2006; 44: 874-80.

[25] Pournik O, Alavian SM, Ghalichi L, et al. Inter-observer and Intra-observer Agreement in Pathological Evaluation of Non-alcoholic Fatty Liver Disease Suspected Liver Biopsies. Hepat Mon 2014; 14: e15167.

[26] Jung ES, Lee $\mathrm{K}, \mathrm{Yu}$ E, et al. Interobserver Agreement on Pathologic Features of Liver Biopsy Tissue in Patients with Nonalcoholic Fatty Liver Disease. J Pathol Transl Med 2016; 50: 190-6.

[27] Kleiner DE, Brunt EM, Van Natta M, et al. Network NSCR. Design and validation of a histological scoring system for nonalcoholic fatty liver disease. Hepatology 2005; 41: 131321.

[28] Bedossa P, Consortium FP. Utility and appropriateness of the fatty liver inhibition of progression (FLIP) algorithm and steatosis, activity, and fibrosis (SAF) score in the evaluation of biopsies of nonalcoholic fatty liver disease. Hepatology 2014; 60: 565-75.

[29] Musso G, Gambino R, Cassader M, Pagano G. Meta-analysis: natural history of non-alcoholic fatty liver disease (NAFLD) and diagnostic accuracy of non-invasive tests for liver disease severity. Ann Med 2011; 43: 617-49.

[30] Anstee QM, Targher G, Day CP. Progression of NAFLD to diabetes mellitus, cardiovascular disease or cirrhosis. Nat Rev Gastroenterol Hepatol 2013; 10: 330-44.

[31] Dulai PS, Singh S, Patel J, et al. Increased risk of mortality by fibrosis stage in non-alcoholic fatty liver disease: Systematic Review and Meta-analysis. Hepatology 2017; 65:1557-65.

[32] Hagström $H$, Nasr P, Ekstedt M, et al. Fibrosis stage but not NASH predicts mortality and time to development of severe liver disease in biopsy-proven NAFLD. Journal of Hepatology 2017; 67:1265-73.

[33] Angulo P, Kleiner DE, Dam-Larsen S, et al. Liver Fibrosis, but No Other Histologic Features, Is Associated With Long-term Outcomes of Patients With Nonalcoholic Fatty Liver Disease. Gastroenterology 2015; 149: 389-97.

[34] Ratziu V, Goodman Z, Sanyal A. Current efforts and trends in the treatment of NASH. Journal of hepatology 2015; 62: S65-S75.

[35] Thoma C, Day CP, Trenell MI. Lifestyle interventions for the treatment of non-alcoholic fatty liver disease in adults: a systematic review. Journal of hepatology 2012; 56: 255-66.

[36] Romero-Gómez M, Zelber-Sagi S, Trenell M. Treatment of NAFLD with diet, physical activity and exercise. Journal of hepatology 2017; 67: 829-46.

[37] Collaboration NCDRF. Worldwide trends in diabetes since 1980: a pooled analysis of 751 population-based studies with 4.4 million participants. Lancet 2016; 387: 1513-30.

[38] Williams CD, Stengel J, Asike MI, et al. Prevalence of Nonalcoholic Fatty Liver Disease and Nonalcoholic Steatohepatitis Among a Largely Middle-Aged Population Utilizing Ultrasound and Liver Biopsy: A Prospective Study. Gastroenterology 2011; 140: 124-31.

[39] Bjorkstrom K, Stal P, Hultcrantz R, Hagstrom H. Histologic Scores for Fat and Fibrosis Associate With Development of Type 2 Diabetes in Patients With Nonalcoholic Fatty Liver Disease. Clin Gastroenterol Hepatol 2017; 15: 1461-8.

[40] Park SK, Seo MH, Shin HC, Ryoo JH. Clinical availability of nonalcoholic fatty liver disease as an early predictor of type 2 diabetes mellitus in Korean men: 5 -year prospective cohort study. Hepatology 2013; 57: 1378-83. 
[41] Lonardo A, Bellentani S, Argo CK, et al. Epidemiological modifiers of non-alcoholic fatty liver disease: Focus on high-risk groups. Digestive and Liver Disease 2015; 47: 997-1006.

[42] Younossi ZM, Golabi P, de Avila L, et al. The Global Epidemiology of NAFLD and NASH in Patients with type 2 diabetes: A Systematic Review and Meta-analysis. Journal of Hepatology 2019; 71: 793-801.

[43] Ma J, Hwang S-J, Pedley A, et al. Bi-directional analysis between fatty liver and cardiovascular disease risk factors. Journal of Hepatology 2017; 66: 390-7.

[44] Li Y, Wang J, Tang Y, et al. Bidirectional association between nonalcoholic fatty liver disease and type 2 diabetes in Chinese population: Evidence from the Dongfeng-Tongji cohort study. PLOS ONE 2017; 12: e0174291.

[45] Ballestri S, Zona S, Targher G, et al. Nonalcoholic fatty liver disease is associated with an almost two-fold increased risk of incident type 2 diabetes and metabolic syndrome. Evidence from a systematic review and meta-analysis. J Gastroenterol Hepatol 2016; 31: 936-44.

[46] Chen SC-C, Tsai SP, Jhao J-Y, Jiang W-K, Tsao CK, Chang L-Y. Liver Fat, Hepatic Enzymes, Alkaline Phosphatase and the Risk of Incident Type 2 Diabetes: A Prospective Study of 132,377 Adults. Scientific Reports 2017; 7.

[47] Ekstedt M, Franzén LE, Mathiesen UL, et al. Long-term follow-up of patients with NAFLD and elevated liver enzymes. Hepatology 2006; 44: 865-73.

[48] Nasr P, Ignatova S, Kechagias S, Ekstedt M. Natural history of nonalcoholic fatty liver disease: A prospective follow-up study with serial biopsies. Hepatol Commun 2018; 2: 199-210.

[49] McPherson S, Hardy T, Henderson E, Burt AD, Day CP, Anstee QM. Evidence of NAFLD Progression from Steatosis to Fibrosing-Steatohepatitis Using Paired Biopsies: Implications for Prognosis \& Clinical Management. J Hepatol 2015; 62:1148-55.

[50] Lee RG. Nonalcoholic steatohepatitis: a study of 49 patients. Hum Pathol 1989; 20: 594-8.

[51] Powell EE, Cooksley WG, Hanson R, Searle J, Halliday JW, Powell LW. The natural history of nonalcoholic steatohepatitis: a follow-up study of forty-two patients for up to 21 years. Hepatology 1990; 11: 74-80.

[52] Teli MR, James OF, Burt AD, Bennett MK, Day CP. The natural history of nonalcoholic fatty liver: a follow-up study. Hepatology 1995; 22: 1714-9.

[53] Evans CD, Oien KA, MacSween RN, Mills PR. Non-alcoholic steatohepatitis: a common cause of progressive chronic liver injury? J Clin Pathol 2002; 55: 689-92.

[54] Ratziu V, Giral P, Charlotte F, et al. Liver fibrosis in overweight patients. Gastroenterology 2000; 118: 1117-23.

[55] Harrison SA, Torgerson S, Hayashi PH. The natural history of nonalcoholic fatty liver disease: a clinical histopathological study. Am J Gastroenterol 2003; 98: 2042-7.

[56] Fassio E, Alvarez E, Domínguez N, Landeira G, Longo C. Natural history of nonalcoholic steatohepatitis: a longitudinal study of repeat liver biopsies. Hepatology 2004; 40: 820-6.

[57] Adams LA, Sanderson S, Lindor KD, Angulo P. The histological course of nonalcoholic fatty liver disease: a longitudinal study of 103 patients with sequential liver biopsies. J Hepatol 2005; 42: 132-8.

[58] Hui AY, Wong VW, Chan HL, et al. Histological progression of non-alcoholic fatty liver disease in Chinese patients. Aliment Pharmacol Ther 2005; 21: 407-13.

[59] Wong VW, Wong GL, Choi PC, et al. Disease progression of non-alcoholic fatty liver disease: a prospective study with paired liver biopsies at 3 years. Gut 2010; 59: 969-74.

[60] Pais R, Charlotte F, Fedchuk L, et al. A systematic review of follow-up biopsies reveals disease progression in patients with non-alcoholic fatty liver. J Hepatol 2013; 59: 550-6.

[61] Sanyal AJ, Harrison SA, Ratziu V, et al. The Natural History of Advanced Fibrosis due to Nonalcoholic Steatohepatitis: Data from the Simtuzumab Trials. Hepatology 2019; 70: 191327.

[62] Stepanova M, Rafiq N, Makhlouf $\mathrm{H}$, et al. Predictors of all-cause mortality and liver-related mortality in patients with non-alcoholic fatty liver disease (NAFLD). Dig Dis Sci 2013; 58: 3017-23. 
[63] Adams LA, Harmsen S, St Sauver JL, et al. Nonalcoholic fatty liver disease increases risk of death among patients with diabetes: a community-based cohort study. Am J Gastroenterol 2010; 105: 1567-73.

[64] Sebastiani G, Alshaalan R, Wong P, et al. Prognostic value of non-invasive fibrosis and steatosis tools, hepatic venous pressure gradient (HVPG) and histology in nonalcoholic steatohepatitis. PLoS One 2015; 10: e0128774.

[65] Vilar-Gomez E, Calzadilla-Bertot L, Wong VW-S, et al. Fibrosis severity as a determinant of cause-specific mortality in patients with advanced nonalcoholic fatty liver disease: a multinational cohort study. Gastroenterology 2018; 155: 443-57.

[66] Cho N, Shaw J, Karuranga S, et al. IDF Diabetes Atlas: Global estimates of diabetes prevalence for 2017 and projections for 2045. Diabetes research and clinical practice 2018; 138: 271-81.

[67] Collaboration ERF. Diabetes mellitus, fasting glucose, and risk of cause-specific death. New England Journal of Medicine 2011; 364: 829-41.

[68] Muggeo $M$, Verlato $G$, Bonora $E$, et al. The Verona diabetes study: a population-based survey on known diabetes mellitus prevalence and 5-year all-cause mortality. Diabetologia 1995; 38: 318-325.

[69] Weiderpass E, Gridley G, Nyrén O, Pennello G, Landström AS, Ekbom A. Cause-specific mortality in a cohort of patients with diabetes mellitus: a population-based study in Sweden. Journal of clinical epidemiology 2001; 54: 802-9.

[70] Zoppini G, Fedeli U, Gennaro N, Saugo M, Targher G, Bonora E. Mortality from chronic liver diseases in diabetes. In: ed.^^eds. Nature Publishing Group 2014.

[71] Campbell PT, Newton CC, Patel AV, Jacobs EJ, Gapstur SM. Diabetes and cause-specific mortality in a prospective cohort of one million US adults. Diabetes care 2012; 35: 1835-44.

[72] Wideroff L, Gridley G, Chow W-H, et al. Cancer incidence in a population-based cohort of patients hospitalized with diabetes mellitus in Denmark. Journal of the National Cancer Institute 1997; 89: 1360-5.

[73] Yu MC, Henderson BE, Tong MJ, Govindarajan S. Nonviral risk factors for hepatocellular carcinoma in a low-risk population, the non-Asians of Los Angeles County, California. J Natl Cancer Inst 1991; 83: 1820-6.

[74] Kingston M, Ali MA, Atiyeh M, Donnelly R. Diabetes mellitus in chronic active hepatitis and cirrhosis. Gastroenterology 1984; 87: 688-94.

[75] Dyson J, Jaques B, Chattopadyhay D, et al. Hepatocellular cancer: the impact of obesity, type 2 diabetes and a multidisciplinary team. Journal of hepatology 2014; 60: 110-7.

[76] El-Serag HB, Tran T, Everhart JE. Diabetes increases the risk of chronic liver disease and hepatocellular carcinoma. Gastroenterology 2004; 126: 460-8.

[77] Davila J, Morgan R, Shaib Y, McGlynn K, El-Serag H. Diabetes increases the risk of hepatocellular carcinoma in the United States: a population based case control study. Gut 2005; 54: 533-9.

[78] White DL, Kanwal F, El-Serag HB. Association between nonalcoholic fatty liver disease and risk for hepatocellular cancer, based on systematic review. Clin Gastroenterol Hepatol 2012; 10: 1342-59.

[79] Wang P, Kang D, Cao W, Wang Y, Liu Z. Diabetes mellitus and risk of hepatocellular carcinoma: a systematic review and meta-analysis. Diabetes/metabolism research and reviews 2012; 28: 109-22.

[80] Bugianesi E, Leone N, Vanni E, et al. Expanding the natural history of nonalcoholic steatohepatitis: from cryptogenic cirrhosis to hepatocellular carcinoma. Gastroenterology 2002; 123: 134-40.

[81] Marrero JA, Fontana RJ, Su GL, Conjeevaram HS, Emick DM, Lok AS. NAFLD may be a common underlying liver disease in patients with hepatocellular carcinoma in the United States. Hepatology 2002; 36: 1349-54.

[82] Regimbeau JM, Colombat M, Mognol $\mathrm{P}$, et al. Obesity and diabetes as a risk factor for hepatocellular carcinoma. Liver Transplantation 2004; 10: S69-S73. 
[83] Hughes V. The big fat truth. Nature 2013; 497: 428-30.

[84] Prospective Studies C, Whitlock G, Lewington S, et al. Body-mass index and cause-specific mortality in 900000 adults: collaborative analyses of 57 prospective studies. Lancet 2009; 373: 1083-96.

[85] Berrington de Gonzalez A, Hartge P, Cerhan JR, et al. Body-mass index and mortality among 1.46 million white adults. N Engl J Med 2010; 363: 2211-9.

[86] Flegal KM, Kit BK, Orpana H, Graubard BI. Association of all-cause mortality with overweight and obesity using standard body mass index categories: a systematic review and metaanalysis. JAMA 2013; 309: 71-82.

[87] Li L, Liu DW, Yan HY, Wang ZY, Zhao SH, Wang B. Obesity is an independent risk factor for non-alcoholic fatty liver disease: evidence from a meta-analysis of 21 cohort studies. Obes Rev 2016; 17: 510-9.

[88] Lazo M, Hernaez R, Eberhardt MS, et al. Prevalence of nonalcoholic fatty liver disease in the United States: the Third National Health and Nutrition Examination Survey, 1988-1994. Am J Epidemiol 2013; 178: 38-45.

[89] Reeder SB, Sirlin CB. Quantification of Liver Fat with Magnetic Resonance Imaging 2010; 18: 337-57.

[90] Reeder SB, Cruite I, Hamilton G, Sirlin CB. Quantitative Assessment of Liver Fat with Magnetic Resonance Imaging and Spectroscopy. J Magn Reson Imaging 2011; 34: 729-49.

[91] Szczepaniak LS, Nurenberg P, Leonard D, et al. Magnetic resonance spectroscopy to measure hepatic triglyceride content: prevalence of hepatic steatosis in the general population. Am J Physiol Endocrinol Metab 2005; 288: E462-8.

[92] Loomba R, Sirlin CB, Ang B, et al. Ezetimibe for the treatment of nonalcoholic steatohepatitis: Assessment by novel MRI and MRE in a randomized trial (MOZART Trial). Hepatology 2015; 61: 1239-50.

[93] Browning JD, Szczepaniak LS, Dobbins R, et al. Prevalence of hepatic steatosis in an urban population in the United States: impact of ethnicity. Hepatology 2004; 40: 1387-95.

[94] Tang A, Tan J, Sun M, Hamilton G, et al. Nonalcoholic fatty liver disease: MR imaging of liver proton density fat fraction to assess hepatic steatosis. Radiology 2013; 267: 422-31.

[95] Tang A, Desai A, Hamilton G, et al. Accuracy of MR imaging-estimated proton density fat fraction for classification of dichotomized histologic steatosis grades in nonalcoholic fatty liver disease. Radiology 2015; 274: 416-25.

[96] Hong CW, Hamilton G, Hooker C, et al. Measurement of spleen fat on MRI-proton density fat fraction arises from reconstruction of noise. Abdominal Radiology 2019; 44: 3295-303.

[97] Rehm JL, Wolfgram PM, Hernando D, Eickhoff JC, Allen DB, Reeder SB. Proton density fatfraction is an accurate biomarker of hepatic steatosis in adolescent girls and young women. European Radiology 2015; 25: 2921-30.

[98] Nasr P, Forsgren MF, Ignatova S, et al. Using a 3\% Proton Density Fat Fraction as a Cut-Off Value Increases Sensitivity of Detection of Hepatic Steatosis, Based on Results From Histopathology Analysis. Gastroenterology 2017; 153: 53-5.

[99] Xu C, Yu C, Ma H, Xu L, Miao M, Li Y. Prevalence and risk factors for the development of nonalcoholic fatty liver disease in a nonobese Chinese population: the Zhejiang Zhenhai Study. Am J Gastroenterol 2013; 108: 1299-304.

[100] Wu J, He S, Xu H, et al. Non-alcoholic fatty liver disease incidence, remission and risk factors among a general Chinese population with a 6-year follow-up. Sci Rep 2018; 8: 7557.

[101] VanWagner LB, Khan SS, Ning H, et al. Body mass index trajectories in young adulthood predict non-alcoholic fatty liver disease in middle age: The CARDIA cohort study. Liver Int 2018; 38: 706-14.

[102] Centis E, Marzocchi R, Di Domizio S, Ciaravella MF, Marchesini G. The effect of lifestyle changes in non-alcoholic fatty liver disease. Dig Dis 2010; 28: 267-73. 
[103] Zelber-Sagi S, Lotan R, Shlomai A, et al. Predictors for incidence and remission of NAFLD in the general population during a seven-year prospective follow-up. J Hepatol 2012; 56: 114551.

[104] Mathurin P, Gonzalez F, Kerdraon O, et al. The evolution of severe steatosis after bariatric surgery is related to insulin resistance. Gastroenterology 2006; 130: 1617-24.

[105] Mathurin P, Hollebecque A, Arnalsteen L, et al. Prospective study of the long-term effects of bariatric surgery on liver injury in patients without advanced disease. Gastroenterology 2009; 137: 532-40.

[106] Rabl C, Campos GM. The impact of bariatric surgery on nonalcoholic steatohepatitis. Semin Liver Dis 2012; 32: 80-91.

[107] Vilar-Gomez E, Martinez-Perez Y, Calzadilla-Bertot L, et al. Weight Loss Through Lifestyle Modification Significantly Reduces Features of Nonalcoholic Steatohepatitis. Gastroenterology 2015; 149: 367-78.

[108] Hagstrom H, Stal P, Hultcrantz R, Hemmingsson T, Andreasson A. Overweight in late adolescence predicts development of severe liver disease later in life: A 39years follow-up study. J Hepatol 2016; 65: 363-8.

[109] Liu B, Balkwill A, Reeves G, Beral V, Million Women Study C. Body mass index and risk of liver cirrhosis in middle aged UK women: prospective study. BMJ 2010; 340: c912.

[110] Ioannou GN, Weiss NS, Kowdley KV, Dominitz JA. Is obesity a risk factor for cirrhosis-related death or hospitalization? A population-based cohort study. Gastroenterology 2003; 125: 1053-9.

[111] Calle EE, Rodriguez C, Walker-Thurmond K, Thun MJ. Overweight, obesity, and mortality from cancer in a prospectively studied cohort of U.S. adults. N Engl J Med 2003; 348: 1625-38.

[112] Hagstrom $\mathrm{H}$, Tynelius $\mathrm{P}$, Rasmussen $\mathrm{F}$. High BMI in late adolescence predicts future severe liver disease and hepatocellular carcinoma: a national, population-based cohort study in 1.2 million men. Gut 2018; 67: 1536-42.

[113] Williams R, Aspinall R, Bellis M, et al. Addressing liver disease in the UK: a blueprint for attaining excellence in health care and reducing premature mortality from lifestyle issues of excess consumption of alcohol, obesity, and viral hepatitis. Lancet 2014; 384: 1953-97.

[114] European Association for the Study of the L, European Association for the Study of D, European Association for the Study of O. EASL-EASD-EASO Clinical Practice Guidelines for the management of non-alcoholic fatty liver disease. J Hepatol 2016; 64: 1388-402.

[115] Becker U, Deis A, Sorensen T, et al. Prediction of risk of liver disease by alcohol intake, sex, and age: a prospective population study. Hepatology 1996; 23: 1025-9.

[116] Adams LA, Anstee QM, Tilg H, Targher G. Non-alcoholic fatty liver disease and its relationship with cardiovascular disease and other extrahepatic diseases. Gut 2017; 66: 1138-53.

[117] Schrieks IC, Heil AL, Hendriks HF, Mukamal KJ, Beulens JW. The effect of alcohol consumption on insulin sensitivity and glycemic status: a systematic review and meta-analysis of intervention studies. Diabetes care 2015; 38: 723-32.

[118] Thursz M, Gual A, Lackner C, et al. EASL Clinical Practice Guidelines: Management of alcoholrelated liver disease. Journal of Hepatology 2018; 69: 154-81.

[119] Saunders JB, Aasland OG, Babor TF, de la Fuente JR, Grant M. Development of the Alcohol Use Disorders Identification Test (AUDIT): WHO Collaborative Project on Early Detection of Persons with Harmful Alcohol Consumption--II. Addiction 1993; 88: 791-804.

[120] Niemelä O. Biomarker-Based Approaches for Assessing Alcohol Use Disorders. 2016; 13: 166.

[121] Kechagias S, Dernroth DN, Blomgren A, et al. Phosphatidylethanol Compared with Other Blood Tests as a Biomarker of Moderate Alcohol Consumption in Healthy Volunteers: A Prospective Randomized Study. Alcohol and Alcoholism 2015; 50: 399-406.

[122] Cao G, Yi T, Liu Q, Wang M, Tang S. Alcohol consumption and risk of fatty liver disease: a meta-analysis. PeerJ 2016; 4:e2633.

[123] Moriya A, Iwasaki Y, Ohguchi S, et al. Roles of alcohol consumption in fatty liver: A longitudinal study. J Hepatol 2015; 62: 921-7. 
[124] Kechagias S, Zanjani S, Gjellan S, et al. Effects of moderate red wine consumption on liver fat and blood lipids: a prospective randomized study. Annals of medicine 2011; 43: 545-54.

[125] Chang Y, Cho YK, Kim Y, et al. Nonheavy Drinking and Worsening of Noninvasive Fibrosis Markers in Nonalcoholic Fatty Liver Disease: A Cohort Study. Hepatology 2019; 69: 64-75.

[126] Ekstedt $M$, Hagström H, Nasr P, et al. Fibrosis stage is the strongest predictor for diseasespecific mortality in NAFLD after up to 33 years of follow-up. Hepatology 2015; 61: 1547-54.

[127] Dunn W, Sanyal AJ, Brunt EM, et al. Modest alcohol consumption is associated with decreased prevalence of steatohepatitis in patients with non-alcoholic fatty liver disease (NAFLD). J Hepatol 2012; 57:384-91.

[128] Hagström H, Nasr P, Ekstedt $M$, et al. Low to moderate lifetime alcohol consumption is associated with less advanced stages of fibrosis in non-alcoholic fatty liver disease. Scandinavian Journal of Gastroenterology 2017; 52: 159-65.

[129] Ekstedt M, Franzén LE, Holmqvist $M$, et al. Alcohol consumption is associated with progression of hepatic fibrosis in non-alcoholic fatty liver disease. Scand I Gastroenterol 2009; 44:366-74.

[130] Ajmera V, Belt P, Wilson LA, et al. Among patients with nonalcoholic fatty liver disease, modest alcohol use is associated with less improvement in histologic steatosis and steatohepatitis. Clinical Gastroenterology and Hepatology 2018; 16: 1511-20.

[131] Mahli A, Hellerbrand C. Alcohol and obesity: a dangerous association for fatty liver disease. Digestive Diseases 2016; 34: 32-39.

[132] Kimura T, Tanaka N, Fujimori N, et al. Mild drinking habit is a risk factor for hepatocarcinogenesis in non-alcoholic fatty liver disease with advanced fibrosis. World journal of gastroenterology 2018; 24: 1440.

[133] Hajifathalian K, Torabi Sagvand B, McCullough AJ. Effect of Alcohol Consumption on Survival in Nonalcoholic Fatty Liver Disease: A National Prospective Cohort Study. Hepatology 2019; 70:511-21.

[134] Ronksley PE, Brien SE, Turner BJ, Mukamal KJ, Ghali WA. Association of alcohol consumption with selected cardiovascular disease outcomes: a systematic review and meta-analysis. BMJ 2011; 342: d671.

[135] Romeo S, Kozlitina J, Xing C, Pertsemlidis A, Cox D, Pennacchio LA, Boerwinkle E, Cohen JC, Hobbs HH. Genetic variation in PNPLA3 confers susceptibility to nonalcoholic fatty liver disease. Nature genetics 2008; 40: 1461.

[136] Speliotes EK, Butler JL, Palmer CD, Voight BF, Consortium GCtM, CRN N, Hirschhorn JN. PNPLA3 variants specifically confer increased risk for histologic nonalcoholic fatty liver disease but not metabolic disease. Hepatology 2010; 52: 904-12.

[137] Kozlitina J, Smagris E, Stender S, et al. Exome-wide association study identifies a TM6SF2 variant that confers susceptibility to nonalcoholic fatty liver disease. Nature genetics 2014; 46: 352.

[138] Kawaguchi T, Sumida Y, Umemura A, et al. Genetic polymorphisms of the human PNPLA3 gene are strongly associated with severity of non-alcoholic fatty liver disease in Japanese. PloS one 2012; 7: e38322.

[139] Trepo E, Guyot E, Ganne-Carrie N, et al. PNPLA3 (rs738409 C> G) is a common risk variant associated with hepatocellular carcinoma in alcoholic cirrhosis. Hepatology 2012; 55: 1307-8.

[140] Trépo E, Nahon P, Bontempi G, et al. Association between the PNPLA3 (rs738409 C> G) variant and hepatocellular carcinoma: evidence from a meta-analysis of individual participant data. Hepatology 2014; 59: 2170-7.

[141] Liu Y-L, Patman G, Leathart J, et al. Carriage of the PNPLA3 rs738409 C> G polymorphism confers an increased risk of non-alcoholic fatty liver disease associated hepatocellular carcinoma. Journal of hepatology 2014; 61: 75-81.

[142] Emdin CA, Haas M, Khera AV, et al. A missense variant in Mitochondrial Amidoxime Reducing Component 1 gene and protection against liver disease. BioRxiv 2019: 594523. 
[143] Ma Y, Belyaeva OV, Brown PM, et al. 17-Beta Hydroxysteroid Dehydrogenase 13 Is a Hepatic Retinol Dehydrogenase Associated With Histological Features of Nonalcoholic Fatty Liver Disease. Hepatology 2019; 69: 1504-19.

[144] Abul-Husn NS, Cheng X, Li AH, et al. A protein-truncating HSD17B13 variant and protection from chronic liver disease. New England Journal of Medicine 2018; 378: 1096-106.

[145] Mancina RM, Dongiovanni P, Petta S, et al. The MBOAT7-TMC4 variant rs641738 increases risk of nonalcoholic fatty liver disease in individuals of European descent. Gastroenterology 2016; 150: 1219-30.

[146] Sookoian S, Flichman D, Garaycoechea ME, et al. Lack of evidence supporting a role of TMC4rs641738 missense variant-MBOAT7-intergenic downstream variant-in the Susceptibility to Nonalcoholic Fatty Liver Disease. Scientific reports 2018; 8: 5097.

[147] Speliotes EK, Yerges-Armstrong LM, Wu J, et al. Genome-wide association analysis identifies variants associated with nonalcoholic fatty liver disease that have distinct effects on metabolic traits. PLoS genetics 2011; 7: e1001324.

[148] Chambers JC, Zhang W, Sehmi J, et al. Genome-wide association study identifies loci influencing concentrations of liver enzymes in plasma. Nature genetics 2011; 43: 1131.

[149] Bacon BR, Farahvash MJ, Janney CG, Neuschwander-Tetri BA. Nonalcoholic steatohepatitis: an expanded clinical entity. Gastroenterology 1994; 107: 1103-9.

[150] Nelson JE, Wilson L, Brunt EM, et al. Relationship between the pattern of hepatic iron deposition and histological severity in nonalcoholic fatty liver disease. Hepatology 2011; 53: 448-57.

[151] Fargion S, Mattioli M, Fracanzani AL, et al. Hyperferritinemia, iron overload, and multiple metabolic alterations identify patients at risk for nonalcoholic steatohepatitis. The American journal of gastroenterology 2001; 96: 2448.

[152] Bonkovsky HL, Jawaid Q, Tortorelli K, et al. Non-alcoholic steatohepatitis and iron: increased prevalence of mutations of the HFE gene in non-alcoholic steatohepatitis. Journal of hepatology 1999; 31: 421-9.

[153] George DK, Goldwurm S, Macdonald GA, et al. Increased hepatic iron concentration in nonalcoholic steatohepatitis is associated with increased fibrosis. Gastroenterology 1998; 114: 311-8.

[154] Bugianesi E, Manzini P, D'Antico S, et al. Relative contribution of iron burden, HFE mutations, and insulin resistance to fibrosis in nonalcoholic fatty liver. Hepatology 2004; 39: 179-87.

[155] Manousou P, Kalambokis G, Grillo F, et al. Serum ferritin is a discriminant marker for both fibrosis and inflammation in histologically proven non-alcoholic fatty liver disease patients. Liver International 2011; 31: 730-9.

[156] Fracanzani AL, Valenti L, Bugianesi E, et al. Risk of nonalcoholic steatohepatitis and fibrosis in patients with nonalcoholic fatty liver disease and low visceral adiposity. Journal of hepatology 2011; 54: 1244-9.

[157] Kowdley KV, Belt P, Wilson LA, et al. Serum ferritin is an independent predictor of histologic severity and advanced fibrosis in patients with nonalcoholic fatty liver disease. Hepatology 2012; 55: 77-85.

[158] Hagström $H$, Nasr P, Bottai $M$, et al. Elevated serum ferritin is associated with increased mortality in non-alcoholic fatty liver disease after 16 years of follow-up. Liver International 2016; 36: 1688-95.

[159] Angulo P, George J, Day CP, et al. Serum ferritin levels lack diagnostic accuracy for liver fibrosis in patients with nonalcoholic fatty liver disease. Clinical Gastroenterology and Hepatology 2014; 12: 1163-9.

[160] Valenti L, Fracanzani AL, Dongiovanni P, et al. Iron depletion by phlebotomy improves insulin resistance in patients with nonalcoholic fatty liver disease and hyperferritinemia: evidence from a case-control study. The American journal of gastroenterology 2007; 102: 1251. 
[161] Valenti L, Fracanzani AL, Dongiovanni P, et al. A randomized trial of iron depletion in patients with nonalcoholic fatty liver disease and hyperferritinemia. World journal of gastroenterology 2014; 20: 3002.

[162] Sumida Y, Kanemasa K, Fukumoto K, et al. Effect of iron reduction by phlebotomy in Japanese patients with nonalcoholic steatohepatitis: A pilot study. Hepatology research 2006; 36: 31521.

[163] Beaton M, Chakrabarti S, Levstik M, Speechley M, Marotta P, Adams P. Phase II clinical trial of phlebotomy for non-alcoholic fatty liver disease. Alimentary pharmacology \& therapeutics 2013; 37: 720-9.

[164] Adams LA, Crawford DH, Stuart K, et al. The impact of phlebotomy in nonalcoholic fatty liver disease: A prospective, randomized, controlled trial. Hepatology 2015; 61: 1555-64.

[165] Maliken BD, Nelson JE, Klintworth HM, Beauchamp M, Yeh MM, Kowdley KV. Hepatic reticuloendothelial system cell iron deposition is associated with increased apoptosis in nonalcoholic fatty liver disease. Hepatology 2013; 57: 1806-13.

[166] Valenti L, Fracanzani AL, Bugianesi E, et al. HFE genotype, parenchymal iron accumulation, and liver fibrosis in patients with nonalcoholic fatty liver disease. Gastroenterology 2010; 138: 905-12.

[167] Karlsson M, Ekstedt M, Dahlström N, et al. Liver R2* is affected by both iron and fat: A dual biopsy-validated study of chronic liver disease. Journal of Magnetic Resonance Imaging 2019; 50: 325-33.

[168] Greene CM, Marciniak SJ, Teckman J, et al. $\alpha 1$-Antitrypsin deficiency. Nature reviews Disease primers 2016; 2: 16051.

[169] Silverman EK, Sandhaus RA. Alpha1-antitrypsin deficiency. New England Journal of Medicine 2009; 360: 2749-57.

[170] Blanco I, Bueno P, Diego I, et al. Alpha-1 antitrypsin Pi* Z gene frequency and Pi* ZZ genotype numbers worldwide: an update. International journal of chronic obstructive pulmonary disease $2017 ; 12: 561$.

[171] de Serres FJ, Blanco I, Fernández-Bustillo E. PI S and PI Z alpha-1 antitrypsin deficiency worldwide. A review of existing genetic epidemiological data. Monaldi Archives for Chest Disease 2007; 67.

[172] Sveger T. Liver disease in alpha1-antitrypsin deficiency detected by screening of 200,000 infants. New England Journal of Medicine 1976; 294: 1316-21.

[173] Silverman EK, Miletich JP, Pierce JA, et al. Alpha-1-antitrypsin deficiency: high prevalence in the St. Louis area determined by direct population screening. American review of respiratory disease 1989; 140: 961-6.

[174] Valenti L, Dongiovanni P, Piperno A, et al. a1-Antitrypsin mutations in NAFLD: High prevalence and association with altered iron metabolism but not with liver damage. Hepatology 2006; 44: 857-64.

[175] Goltz D, Hittetiya K, Vössing LM, Kirfel J, Spengler U, Fischer H-P. a 1-Antitrypsin PiMZ heterozygosity has an independent aggravating effect on liver fibrosis in alcoholic liver disease. Virchows Archiv 2014; 465: 539-46.

[176] Schaefer B, Mandorfer M, Viveiros A, et al. Heterozygosity for the alpha-1-antitrypsin Z allele in cirrhosis is associated with more advanced disease. Liver Transplantation 2018; 24: 74451.

[177] Fischer H-P, Ortiz-Pallardó ME, Ko Y, Esch C, Zhou H. Chronic liver disease in heterozygous a1-antitrypsin deficiency PiZ. Journal of hepatology 2000; 33: 883-92.

[178] Regev A, Guaqueta C, Molina EG, et al. Does the heterozygous state of alpha-1 antitrypsin deficiency have a role in chronic liver diseases? Interim results of a large case-control study. Journal of pediatric gastroenterology and nutrition 2006; 43: S30-S35.

[179] El-Rayah E-GA, Twomey PJ, Wallace EM, McCormick PA. Both $\alpha$-1-antitrypsin Z phenotypes and low caeruloplasmin levels are over-represented in alcohol and nonalcoholic fatty liver 
disease cirrhotic patients undergoing liver transplant in Ireland. European journal of gastroenterology \& hepatology 2018; 30: 364-7.

[180] Strnad P, Buch S, Hamesch K, et al. Heterozygous carriage of the alpha1-antitrypsin Pi* Z variant increases the risk to develop liver cirrhosis. Gut 2019; 68: 1099-107.

[181] Singh S, Allen AM, Wang Z, Prokop L, Murad MH, Loomba R. Fibrosis progression in nonalcoholic fatty liver vs nonalcoholic steatohepatitis: a systematic review and metaanalysis of paired-biopsy studies. Clin Gastroenterol Hepatol 2015; 13: 643-54.

[182] Buzzetti E, Hall A, Ekstedt $M$, et al. Collagen proportion area is an independent predictor of longterm outcome in patients with non-alcoholic fatty liver disease. Aliment Pharmacol Ther 2019; 49: 1214-22.

[183] Hagström H, Nasr P, Ekstedt M, Stål P, Hultcrantz R, Kechagias S. Accuracy of noninvasive scoring systems in assessing risk of death and liver-related endpoints in patients with nonalcoholic fatty liver disease. Clinical Gastroenterology and Hepatology 2019; 17: 1148-56.

[184] Angulo P, Bugianesi E, Bjornsson ES, et al. Simple noninvasive systems predict long-term outcomes of patients with nonalcoholic fatty liver disease. Gastroenterology 2013; 145: 7829.

[185] Brunt EM, Janney CG, Di Bisceglie AM, Neuschwander-Tetri BA, Bacon BR. Nonalcoholic steatohepatitis: a proposal for grading and staging the histological lesions. Am J Gastroenterol 1999; 94: 2467-74.

[186] Nonalcoholic steatohepatitis clinical research network. Hepatology 2003; 37: 244.

[187] Younossi ZM, Stepanova M, Rafiq N, et al. Pathologic criteria for nonalcoholic steatohepatitis: Interprotocol agreement and ability to predict liver-related mortality. Hepatology 2011; 53: 1874-82.

[188] Sanyal AJ, Brunt EM, Kleiner DE, et al. Endpoints and clinical trial design for nonalcoholic steatohepatitis. Hepatology 2011; 54: 344-53.

[189] Hagström H, Nasr P, Ekstedt M, et al. SAF score and mortality in NAFLD after up to 41 years of follow-up. Scand J Gastroenterol 2017; 52: 87-91.

[190] Buzzetti E, Pinzani M, Tsochatzis EA. The multiple-hit pathogenesis of non-alcoholic fatty liver disease (NAFLD). Metabolism 2016; 65: 1038-48.

[191] Puche JE, Saiman Y, Friedman SL. Hepatic stellate cells and liver fibrosis. Comprehensive Physiology 2011; 3: 1473-92.

[192] Argo CK, Northup PG, Al-Osaimi AM, Caldwell SH. Systematic review of risk factors for fibrosis progression in non-alcoholic steatohepatitis. J Hepatol 2009; 51: 371-9.

[193] McPherson S, Pais R, Valenti L, et al. Further delineation of fibrosis progression in NAFLD: evidence from a large cohort of patients with sequential biopsies. In: ed.^eds., The International Liver Congress 2017. Journal of Hepatology: Amsterdam, 2017; pp. S593.

[194] Ajmera V, Park CC, Caussy C, et al. Magnetic Resonance Imaging Proton Density Fat Fraction Associates With Progression of Fibrosis in Patients With Nonalcoholic Fatty Liver Disease. Gastroenterology 2018; 155: 307-10.

[195] Yamaguchi K, Yang L, McCall S, et al. Inhibiting triglyceride synthesis improves hepatic steatosis but exacerbates liver damage and fibrosis in obese mice with nonalcoholic steatohepatitis. Hepatology 2007; 45: 1366-74.

[196] Marra F, Svegliati-Baroni G. Lipotoxicity and the gut-liver axis in NASH pathogenesis. J Hepatol 2018; 68: 280-95.

[197] Lazarus JV, Ekstedt M, Marchesini G, et al. Collaborators EILFNPR. A cross-sectional study of the public health response to non-alcoholic fatty liver disease in Europe. J Hepatol 2020; 72: 14-24.

[198] Tanajewski L, Harris R, Harman DJ, et al. Economic evaluation of a community-based diagnostic pathway to stratify adults for non-alcoholic fatty liver disease: a Markov model informed by a feasibility study. BMJ Open 2017; 7: e015659.

[199] Dixon JB, Bhathal PS, O'brien PE. Nonalcoholic fatty liver disease: predictors of nonalcoholic steatohepatitis and liver fibrosis in the severely obese. Gastroenterology 2001; 121: 91-100. 
[200] Cotrim HP, Freitas LA, Alves E, Almeida A, May DS, Caldwell S. Effects of light-to-moderate alcohol consumption on steatosis and steatohepatitis in severely obese patients. European journal of gastroenterology \& hepatology 2009; 21: 969-72.

[201] Ascha MS, Hanouneh IA, Lopez R, Tamimi TA, Feldstein AF, Zein NN. The incidence and risk factors of hepatocellular carcinoma in patients with nonalcoholic steatohepatitis. Hepatology 2010; 51: 1972-8.

[202] Kwon HK, Greenson JK, Conjeevaram HS. Effect of lifetime alcohol consumption on the histological severity of non-alcoholic fatty liver disease. Liver International 2014; 34: 129-35.

[203] Sookoian S, Flichman D, Castaño GO, Pirola CJ. Mendelian randomisation suggests no beneficial effect of moderate alcohol consumption on the severity of nonalcoholic fatty liver disease. Alimentary pharmacology \& therapeutics 2016; 44: 1224-34.

[204] Yamada K, Mizukoshi E, Seike T, et al. Light alcohol consumption has the potential to suppress hepatocellular injury and liver fibrosis in non-alcoholic fatty liver disease. PloS one 2018; 13: e0191026.

[205] Mitchell T, Jeffrey GP, de Boer B, et al. Type and pattern of alcohol consumption is associated with liver fibrosis in patients with non-alcoholic fatty liver disease. American Journal of Gastroenterology 2018; 113: 1484-93. 


\section{Tables}

Table 1. Serial biopsy studies in patients with NAFLD.

\begin{tabular}{|c|c|c|c|c|c|c|}
\hline $\begin{array}{l}\text { Authors, } \\
\text { year (ref.) }\end{array}$ & $\begin{array}{l}\text { Study design, } \\
\text { Cohort selection } \\
\text { NASH prevalence (\%) } \\
\text { NASH definition } \\
\text { Sample size } \\
\text { Follow-up time (median (range) years) }\end{array}$ & $\begin{array}{l}\text { Age (median (range } \\
\text { or SD) years) } \\
\text { BMI } \mathrm{kg} / \mathrm{m}^{2} \text { or Weight } \\
\text { kg or Obesity \% } \\
\text { T2DM }\end{array}$ & $\begin{array}{l}\text { Fibrosis, } \\
\text { baseline }\end{array}$ & $\begin{array}{l}\text { Fibrosis, } \\
\text { follow-up }\end{array}$ & $\begin{array}{l}\text { Fibrosis } \\
\text { progression, } \\
\text { stable or } \\
\text { regression }\end{array}$ & $\begin{array}{l}\text { Baseline } \\
\text { predictors of } \\
\text { progression }\end{array}$ \\
\hline $\begin{array}{l}\text { Lee } \\
\text { 1989[50] }\end{array}$ & $\begin{array}{l}\text { Retrospective, } \\
\text { Pathology records } \\
\text { NASH } 100 \% \\
\text { Definition NASH: N/A } \\
\text { N=13 } \\
\text { Follow-up: } 3.3(1.2-6.9)\end{array}$ & $\begin{array}{l}\text { Age: } 55.4( \pm 10.7) \\
\text { Obese: } 61 \% \\
\text { T2DM: } 39 \%\end{array}$ & $\begin{array}{l}\text { F0 0(0\%), } \\
\text { F1 3(23\%), } \\
\text { F2 6(46\%), } \\
\text { F3 3(23\%), } \\
\text { F4 1(8\%) }\end{array}$ & $\begin{array}{l}\text { F0 0(0\%), } \\
\text { F1 1(8\%), } \\
\text { F2 6(46\%), } \\
\text { F3 3(23\%), } \\
\text { F4 3(23\%) }\end{array}$ & $\begin{array}{l}\text { P 5/13 } \\
\text { S 8/13 } \\
\text { R 0/13 }\end{array}$ & None \\
\hline $\begin{array}{l}\text { Powell et } \\
\text { al. } \\
1990[51]\end{array}$ & $\begin{array}{l}\text { Retrospective } \\
\text { Tertiary center } \\
\text { NASH } 100 \% \\
\text { Definition NASH: Fat and lobular inflammation w/wo fibrosis } \\
\text { N=13 } \\
\text { Follow-up: } 3.0(2.0-8.5)\end{array}$ & $\begin{array}{l}\text { Age: } 48.9( \pm 11.7) \\
\text { Weight: } 83.0( \pm 14.6) \\
\text { T2DM: } 46 \%\end{array}$ & $\begin{array}{l}\text { F0 5(38\%) } \\
\text { F1-3 7(54\%) } \\
\text { F4 1(8\%) }\end{array}$ & $\begin{array}{l}\text { F0 2(15\%) } \\
\text { F1-3 9(70\%) } \\
\text { F4 2(15\%) }\end{array}$ & $\begin{array}{l}\mathrm{P} 4 / 13 \\
\text { S } 8 / 13 \\
\text { R } 1 / 13\end{array}$ & None \\
\hline $\begin{array}{l}\text { Teli et al. } \\
1995[52]\end{array}$ & $\begin{array}{l}\text { Retrospective, } \\
\text { Pathology records } \\
\text { NASH 0\% (100\% isolated steatosis) } \\
\text { Definition NASH: N/A } \\
\text { N=12 } \\
\text { Follow-up: } 10.3(7.6-16)^{*}\end{array}$ & $\begin{array}{l}\text { Age: } 48.2( \pm 9.8) \\
\text { Weight: } 73( \pm 18) \\
\text { T2DM: N/A }\end{array}$ & $\begin{array}{l}\text { F0 12(100\%) } \\
\text { F1 } 0(0 \%) \\
\text { F2 } 0(0 \%) \\
\text { F3(0\%) } \\
\text { F40(0\%) }\end{array}$ & $\begin{array}{l}\text { F0 11(92\%) } \\
\text { F1 } 1(8 \%) \\
\text { F2 0(0\%) } \\
\text { F3(0\%) } \\
\text { F4 } 0(0 \%)\end{array}$ & $\begin{array}{l}\text { P 1/1 } \\
\text { S 11/12 } \\
\text { R 0/12 }\end{array}$ & None \\
\hline $\begin{array}{l}\text { Ratziu et } \\
\text { al. } \\
2000[54]\end{array}$ & $\begin{array}{l}\text { Retrospective, } \\
\text { Tertiary referral } \\
\text { NASH: } 29 \% \\
\text { Definition NASH: Necroinflammation (lobular necrosis and/or piecemeal } \\
\text { necrosis) } \\
\mathrm{N}=14 \\
\text { Follow-up: } 5(1.5-15)\end{array}$ & $\begin{array}{l}\text { Age: } 49(20-79)^{\dagger} \\
\text { BMI: } 29(25-47)^{\dagger} \\
\text { T2DM: } 16 \%{ }^{\dagger}\end{array}$ & $\begin{array}{l}\text { F0 } 4(29 \%) \\
\text { F1 10(71\%) } \\
\text { F2 0(0\%) } \\
\text { F3 0(0\%) } \\
\text { F4 0(0\%) }\end{array}$ & $\begin{array}{l}\text { F0 } 8(57 \%) \\
\text { F1 4(29\%) } \\
\text { F2 1(7\%) } \\
\text { F3 } 0(0 \%) \\
\text { F4 } 1(7 \%)\end{array}$ & $\begin{array}{l}\text { P } 2 / 14 \\
\text { S } 8 / 14 \\
\text { R 4/18 }\end{array}$ & None \\
\hline $\begin{array}{l}\text { Evans et al. } \\
2002[53]\end{array}$ & $\begin{array}{l}\text { Retrospective, } \\
\text { Pathology records } \\
\text { NASH 100\% } \\
\text { Definition NASH: Brunt et al } \\
\text { N=7 } \\
\text { Follow-up: } 7 \text { (5.5-14) }\end{array}$ & $\begin{array}{l}\text { Age: } 57.5( \pm 8.4) \\
\text { BMI: } 32.4( \pm 4.7) \\
\text { T2DM: } 43 \%\end{array}$ & $\begin{array}{l}\text { F0 } 4(57 \%) \\
\text { F1 } 1(14 \%) \\
\text { F2 2(29\%) } \\
\text { F3 0(0\%) } \\
\text { F4 } 0(0 \%)\end{array}$ & $\begin{array}{l}\text { F0 2(29\%) } \\
\text { F1 1(14\%) } \\
\text { F2 3(43\%) } \\
\text { F3 } 1(14 \%) \\
\text { F4 } 0(0 \%)\end{array}$ & $\begin{array}{l}\text { P } 4 / 7 \\
\text { S } 3 / 7 \\
\text { R } 0 / 7\end{array}$ & None \\
\hline
\end{tabular}




\begin{tabular}{|c|c|c|c|c|c|c|}
\hline $\begin{array}{l}\text { Harrison et } \\
\text { al. } \\
2003[55]\end{array}$ & $\begin{array}{l}\text { Retrospective, } \\
\text { Pathology records/tertiary center } \\
\text { NASH: } 41 \% \\
\text { Definition NASH: Brunt et al } \\
\text { N=22 } \\
\text { Follow-up: } 5.7 \text { (1.4-15.7) }\end{array}$ & $\begin{array}{l}\text { Age: } 50.6(33-64) \\
\text { BMI: } 33.8(26.5-48.6) \\
\text { T2DM: } 41 \%\end{array}$ & $\begin{array}{l}\text { F0-2 20(91\%) } \\
\text { F3-4 2(9\%) }\end{array}$ & $\begin{array}{l}\text { F0-2 18(82\%) } \\
\text { F3-4 4(18\%) }\end{array}$ & $\begin{array}{l}\text { P 7/22 } \\
\text { S 11/22 } \\
\text { R 4/22 }\end{array}$ & AST \\
\hline $\begin{array}{l}\text { Fassio et } \\
\text { al. } \\
2004[56]\end{array}$ & $\begin{array}{l}\text { Prospective, tertiary referral } \\
\text { NASH: } 100 \% \\
\text { Definition NASH: Macrovesicular steatosis (> 10\%) + lobular inflammation }+ \\
\text { ballooning, Mallory hyaline fibrosis, sinusoidal fibrosis or a combination thereof. } \\
\text { N=22 } \\
\text { Follow-up: } 4.3(3-14.3)\end{array}$ & $\begin{array}{l}\text { Age: } 45 \text { (20-69) } \\
\text { BMI: } 30(24-38) \\
\text { T2DM } 36 \%\end{array}$ & $\begin{array}{l}\text { F0 3(14\%) } \\
\text { F1 } 11(50 \%) \\
\text { F2 } 4(18 \%) \\
\text { F3 } 4(18 \%) \\
\text { F4 } 0(0 \%)\end{array}$ & $\begin{array}{l}\text { F0 3(14\%) } \\
\text { F1 11(50\%) } \\
\text { F2 4(18\%) } \\
\text { F3 4(18\%) } \\
\text { F4 } 0(0 \%)\end{array}$ & $\begin{array}{l}\text { P } 7 / 22 \\
\text { S } 11 / 22 \\
\text { R 4/22 }\end{array}$ & $\begin{array}{l}\text { Obesity and } \\
\text { BMI }\end{array}$ \\
\hline $\begin{array}{l}\text { Adams et } \\
\text { al. } \\
2005[57]\end{array}$ & $\begin{array}{l}\text { Retrospective, } \\
\text { Pathology records } \\
\text { NASH: 93\% } \\
\text { Definition NASH: Steatosis + lobular inflammation + ballooning OR steatosis + } \\
\text { any stage of fibrosis } \\
\text { N=103 } \\
\text { Follow-up: } 3.2(0.7-21.3)\end{array}$ & $\begin{array}{l}\text { Age: } 45(19-65) \\
\text { Obese: } 67 \% \\
\text { T2DM: } 42 \%\end{array}$ & $\begin{array}{l}\text { F0 25(25\%) } \\
\text { F1 21(20\%) } \\
\text { F2 23(22\%) } \\
\text { F3 18(18\%) } \\
\text { F4 16(16\%) }\end{array}$ & $\begin{array}{l}\text { F0 26(25\%) } \\
\text { F1 12(12\%) } \\
\text { F2 23(22\%) } \\
\text { F3 23(22\%) } \\
\text { F4 19(18\%) }\end{array}$ & $\begin{array}{l}\text { P 38/103 } \\
\text { S 35/103 } \\
\text { R 30/103 }\end{array}$ & $\begin{array}{l}\text { BMI, T2DM } \\
\text { and Fibrosis } \\
\text { stage }\end{array}$ \\
\hline $\begin{array}{l}\text { Hui et al. } \\
\text { 2005[58] }\end{array}$ & $\begin{array}{l}\text { Retrospective, tertiary referral, } \\
\text { NASH: N/A } \\
\text { Definition NASH: Graded biopsy according to Brunt. } 6 \text { patients hade NAS4-6 } \\
(35 \%) \\
\text { N=17 } \\
\text { Follow-up: } 6.1(3.8-8.0)\end{array}$ & $\begin{array}{l}\text { Age: } 41.8( \pm 10.3) \\
\text { BMI: } 28.6( \pm 3.4) \\
\text { T2DM: } 24 \%\end{array}$ & $\begin{array}{l}\text { F0 11(65\%) } \\
\text { F1 } 5(29 \%) \\
\text { F2 } 1(6 \%) \\
\text { F3 } 0(0 \%) \\
\text { F4 } 0(0 \%)\end{array}$ & $\begin{array}{l}\text { F0 } 5(29 \%) \\
\text { F1 } 8(47 \%) \\
\text { F2 3(18\%) } \\
\text { F3 } 0(0 \%) \\
\text { F4 } 1(6 \% \%)\end{array}$ & $\begin{array}{l}\text { P 9/17 } \\
\text { S 8/17 } \\
\text { R 0/17 }\end{array}$ & None \\
\hline $\begin{array}{l}\text { Ekstedt et } \\
\text { al. } \\
2006[47]\end{array}$ & $\begin{array}{l}\text { Prospective, Tertiary referral } \\
\text { NASH } 49 \% \\
\text { Definition NASH: Steatosis + lobular inflammation + ballooning OR steatosis + } \\
\text { any stage of fibrosis } \\
\mathrm{N}=70 \\
\text { Follow-up: } 13.8(10.3-16.3)\end{array}$ & $\begin{array}{l}\text { Age: } 48 \text { (24-66) } \\
\text { BMI: } 27(21-43) \\
\text { T2DM: 9\% }\end{array}$ & $\begin{array}{l}\text { F0 36(51\%) } \\
\text { F1 19(27\%) } \\
\text { F2 11(16\%) } \\
\text { F3 4(6\%) } \\
\text { F4 0(0\%) }\end{array}$ & $\begin{array}{l}\text { F0 24(34\%) } \\
\text { F1 22(31\%) } \\
\text { F2 11(16\%) } \\
\text { F3 7(10\%) } \\
\text { F4 6(9\%) }\end{array}$ & $\begin{array}{l}\text { P 29/70 } \\
\text { S 30/70 } \\
\text { R 11/70 }\end{array}$ & $\begin{array}{l}\Delta \text { Weight } \\
>5 \mathrm{~kg}, \text { ALT, } \\
\text { AST, Platelet } \\
\text { count, } \\
\text { IR }_{\text {HOMA, SPC }}\end{array}$ \\
\hline $\begin{array}{l}\text { Wong et al. } \\
\text { 2010[59] }\end{array}$ & $\begin{array}{l}\text { Prospective, tertiary referral } \\
\text { NASH: 33\% } \\
\text { Definition NASH: steatosis + hepatocytes ballooning or intralobular hepatocyte } \\
\text { necrosis. } \\
\text { N=52 } \\
\text { Follow-up: } 3\end{array}$ & $\begin{array}{l}\text { Age: } 44( \pm 9) \\
\text { BMI: } 27.4( \pm 3.7) \\
\text { T2DM: } 50 \%\end{array}$ & $\begin{array}{l}\text { F0 26(50\%) } \\
\text { F1 17(33\%) } \\
\text { F2 7(13\%) } \\
\text { F3 } 1(2 \%) \\
\text { F4 } 1(2 \%)\end{array}$ & $\begin{array}{l}\text { F0 28(54\%) } \\
\text { F1 15(29\%) } \\
\text { F2 2(4\%) } \\
\text { F3 4(8\%) } \\
\text { F4 3(6\%) }\end{array}$ & $\begin{array}{l}\text { P } 14 / 52 \\
\text { S 25/52 } \\
\text { R } 13 / 52\end{array}$ & $\begin{array}{l}\text { LDL, } \\
\Delta \mathrm{Weight,} \\
\Delta \mathrm{BMI}\end{array}$ \\
\hline $\begin{array}{l}\text { Pais et al. } \\
\text { 2013[60] }\end{array}$ & $\begin{array}{l}\text { Retrospective, tertiary referral } \\
\text { NASH: } 64 \% \\
\text { Definition NASH: Steatosis + lobular inflammation + ballooning OR steatosis + } \\
\text { lobular inflammation + advanced fibrosis } \\
\text { N=70 } \\
\text { Follow-up: } 3.4 \text { (1-12) }\end{array}$ & $\begin{array}{l}\text { Age: } 52( \pm 10.5) \\
\text { BMI: } 29( \pm 3.6) \\
\text { T2DM: } 35 \%\end{array}$ & $\begin{array}{l}\text { F0 17(24\%) } \\
\text { F1 18(26\%) } \\
\text { F2 13(19\%) } \\
\text { F3 19(27\%) } \\
\text { F4 3(4\%) }\end{array}$ & N/A & $\begin{array}{l}\text { P 20/70 } \\
\text { S 30/70 } \\
\text { R 20/70 }\end{array}$ & N/A \\
\hline
\end{tabular}




\begin{tabular}{|c|c|c|c|c|c|c|}
\hline $\begin{array}{l}\text { McPherson } \\
\text { et al. } \\
\text { 2015[49] }\end{array}$ & $\begin{array}{l}\text { Retrospective, tertiary referral } \\
\text { NASH: } 75 \% \\
\text { Definition NASH: NASH: steatosis + ballooning + inflammation +/- fibrosis. } \\
\text { Also } 3 \text { patients defined as NASH; } 1 \text { because of steatosis + fibrosis } 3 \text { and } 2 \\
\text { because of steatosis + lobular inflammation + fibrosis stage } 2 \\
\text { N=108 } \\
\text { Follow-up: } 6.6(1.3-22.6)\end{array}$ & $\begin{array}{l}\text { Age: } 48( \pm 12) \\
\text { BMI: } 34( \pm 5) \\
\text { T2DM: } 48 \%\end{array}$ & $\begin{array}{l}\text { F0 23(21\%) } \\
\text { F1 29(27\%) } \\
\text { F2 33(31\%) } \\
\text { F3 23(21\%) } \\
\text { F4 0(0\%) }\end{array}$ & $\begin{array}{l}\text { F0 23(21\%) } \\
\text { F1 19(18\%) } \\
\text { F2 19(18\%) } \\
\text { F3 33(31\%) } \\
\text { F4 13(12\%) }\end{array}$ & $\begin{array}{l}\text { P 45/108 } \\
\text { S 43/108 } \\
\text { R 20/108 }\end{array}$ & $\begin{array}{l}\text { AST/ALT } \\
\text { ratio, Platelet } \\
\text { count, Fib4 }\end{array}$ \\
\hline $\begin{array}{l}\text { Sanyal et } \\
\text { al. } \\
2019[61]\end{array}$ & $\begin{array}{l}\text { Prospective, clinical trial data } \\
\text { NASH: 82\% } \\
\text { Definition NASH: NASH CRN (NAS } \geq 4) \\
\text { N=217 } \\
\text { Follow-up: } 2.4(0.03-3.9)\end{array}$ & $\begin{array}{l}\text { Age: } 55 \text { (48-59) } \\
\text { BMI: } 33.7(30.3-38.4) \\
\text { T2DM: } 67 \%\end{array}$ & $\begin{array}{l}\text { F0 } 0(0 \%) \\
\text { F1 } 0(0 \%) \\
\text { F2 } 0(0 \%) \\
\text { F3 217(100\%) } \\
\text { F4 } 0(0 \%)\end{array}$ & N/A & $\begin{array}{l}\text { P 48/217 } \\
\text { S } 127 / 217 \\
\text { R 42/217 }\end{array}$ & $\begin{array}{l}\text { INR, Platelet } \\
\text { count, Hepatic } \\
\text { collagen } \\
\text { content, } \alpha- \\
\text { SMA } \\
\text { expression, } \\
\text { ELF score, } \\
\text { FibroTest, } \\
\text { FIB-4, APRI, } \\
\text { sLOXL2 } \\
\end{array}$ \\
\hline
\end{tabular}

*In a subset of patients $(\mathrm{n}=26)$ who did not have cancer or biochemical signs of autoimmune disease and who did not die during follow-up.

†For entire cohort of 93 patients

$\ddagger$ Only patients with fibrosis stage 3 included in this table.

Abbreviations: ALT, alanine transaminase; APRI, AST to platelet ratio index; AST, aspartate transaminase; BMI, body mass index; ELF, enhanced liver fibrosis; F0-4,

fibrosis stage 0-4; FIB-4, fibrosis-4; INR, international normalized ratio; IR HOMA, homeostatic model assessment for insulin resistance; LDL, low-density lipoprotein; NA, not applicable; NASH, non-alcoholic steatohepatitis; NASH-CRN, NASH-Clinical Research Network; P, progression; R, regression; S, stable; sLOXL2, serum lysyl oxidase like 2; SMA, smooth muscle antibody; SPC, stereological point counting; T2DM, type 2 diabetes mellitus. 
Table 2. Studies assessing the impact of alcohol on histopathology in NAFLD.

\begin{tabular}{|c|c|c|c|c|c|c|c|}
\hline $\begin{array}{l}\text { Author } \\
\text { (year) }\end{array}$ & $\begin{array}{l}\text { Sample } \\
\text { size }\end{array}$ & $\begin{array}{l}\text { Diagnosis of } \\
\text { NAFLD }\end{array}$ & Study design & $\begin{array}{l}\text { Definition of } \\
\text { moderate } \\
\text { alcohol } \\
\text { consumption }\end{array}$ & $\begin{array}{l}\text { Assessment of } \\
\text { alcohol } \\
\text { consumption }\end{array}$ & Focus/highlight & Outcome \\
\hline $\begin{array}{l}\text { Dixon et al. } \\
2001[200]\end{array}$ & 105 & Liver biopsy & Cross-sectional & $<200 \mathrm{~g} /$ week & $\begin{array}{l}\text { Clinical } \\
\text { interview + } \\
\text { questionnaire }\end{array}$ & Liver histology & $\begin{array}{l}\text { No significant } \\
\text { difference in NASH } \\
\text { after adjusting for } \\
\text { insulin resistance and } \\
\text { diabetes }\end{array}$ \\
\hline $\begin{array}{l}\text { Cotrim et } \\
\text { al. } \\
\text { 2009[201] }\end{array}$ & 132 & Liver biopsy & Cross-sectional & $<280 \mathrm{~g} /$ week & $\begin{array}{l}\text { Clinical } \\
\text { interview }\end{array}$ & Liver histology & $\begin{array}{l}\text { No difference in liver } \\
\text { histology }\end{array}$ \\
\hline $\begin{array}{l}\text { Ekstedt et } \\
\text { al. } \\
\text { 2009[129] }\end{array}$ & 71 & Liver biopsy & Cohort & $<140 \mathrm{~g} /$ week & $\begin{array}{l}\text { Clinical } \\
\text { interview }+ \\
\text { questionnaire }\end{array}$ & Fibrosis progression & $\begin{array}{l}\text { Binge drinking was } \\
\text { associated with } \\
\text { higher fibrosis stage }\end{array}$ \\
\hline $\begin{array}{l}\text { Ascha et al. } \\
2010[202]\end{array}$ & 195 & $\begin{array}{l}\text { Cirrhosis (liver } \\
\text { biopsy or } \\
\text { symptoms of } \\
\text { portal } \\
\text { hypertension) } \\
\end{array}$ & Cohort & $<168 \mathrm{~g} /$ week & Not stated & $\mathrm{HCC}$ & $\begin{array}{l}\text { Alcohol consumption } \\
\text { as a risk factor for } \\
\mathrm{HCC}\end{array}$ \\
\hline $\begin{array}{l}\text { Dunn et al. } \\
\text { 2012[127] }\end{array}$ & 582 & Liver biopsy & Cross-sectional & $<140 \mathrm{~g} /$ week & Questionnaire & $\begin{array}{l}\text { Liver histology, } \\
\text { steatohepatitis }\end{array}$ & $\begin{array}{l}\text { Less steatohepatitis } \\
\text { and fibrosis in } \\
\text { moderate consumers }\end{array}$ \\
\hline $\begin{array}{l}\text { Kwon et al. } \\
2014[203]\end{array}$ & 77 & Liver biopsy & Cross-sectional & $<40 \mathrm{~g} /$ week & Questionnaire & $\begin{array}{l}\text { Liver histology, lifetime } \\
\text { consumption }\end{array}$ & $\begin{array}{l}\text { Higher rate of fibrosis } \\
\text { F3/F4 in low/no } \\
\text { consumption group }\end{array}$ \\
\hline $\begin{array}{l}\text { Sookoian } \\
\text { et al. } \\
2016[204]\end{array}$ & 266 & Liver biopsy & $\begin{array}{l}\text { Cross- } \\
\text { sectional/mendelian } \\
\text { randomization }\end{array}$ & $\begin{array}{l}210 \mathrm{~g} / \text { week } \\
\text { (male) } 140 \\
\text { g/week (female) } \\
+ \text { gene carriers }\end{array}$ & $\begin{array}{l}\text { Clinical } \\
\text { interview }\end{array}$ & $\begin{array}{l}\text { Genetic carriers as a } \\
\text { measure of alcohol } \\
\text { consumption, no } \\
\text { protective association } \\
\text { of moderate }\end{array}$ & $\begin{array}{l}\text { Higher rate of } \\
\text { steatosis and } \\
\text { inflammatory } \\
\text { changes in non- } \\
\text { carriers (i.e. drinkers) }\end{array}$ \\
\hline
\end{tabular}




\begin{tabular}{|c|c|c|c|c|c|c|c|}
\hline & & & & & & $\begin{array}{l}\text { consumption on } \\
\text { histology }\end{array}$ & \\
\hline $\begin{array}{l}\text { Hagström } \\
\text { et al. } \\
\text { 2017[128] }\end{array}$ & 120 & Liver biopsy & Cross-sectional & $168 \mathrm{~g} /$ week & $\begin{array}{l}\text { Questionnaire } \\
+ \text { PEth }\end{array}$ & Liver histology & $\begin{array}{l}\text { Reduced risk of } \\
\text { fibrosis in moderate } \\
\text { consumers. Elevated } \\
\text { PEth levels increase } \\
\text { risk of significant } \\
\text { fibrosis }\end{array}$ \\
\hline $\begin{array}{l}\text { Ajmera et } \\
\text { al. } \\
\text { 2018[130] }\end{array}$ & 285 & Liver biopsy & Cohort & $<140 \mathrm{~g} /$ week & $\begin{array}{l}\text { Clinical } \\
\text { interview + } \\
\text { questionnaire }\end{array}$ & Liver histology & $\begin{array}{l}\text { Greater reduction in } \\
\text { steatosis and NASH in } \\
\text { non-drinkers }\end{array}$ \\
\hline $\begin{array}{l}\text { Yamada et } \\
\text { al. } \\
\text { 2018[205] }\end{array}$ & 178 & Liver biopsy & Cross-sectional & $\leq 140 \mathrm{~g} /$ week & Questionnaire & Liver histology & $\begin{array}{l}\text { Lower fibrosis score } \\
\text { in moderate } \\
\text { consumers }\end{array}$ \\
\hline $\begin{array}{l}\text { Mitchell et } \\
\text { al. } \\
\text { 2018[206] }\end{array}$ & 187 & Liver biopsy & Cross-sectional & $\begin{array}{l}210 \mathrm{~g} / \text { week } \\
\text { (male) } 140 \\
\mathrm{~g} / \text { week (female) }\end{array}$ & $\begin{array}{l}\text { Clinical } \\
\text { interview + } \\
\text { questionnaire }\end{array}$ & $\begin{array}{l}\text { Fibrosis, binge- } \\
\text { drinking, type of } \\
\text { alcohol }\end{array}$ & $\begin{array}{l}\text { Less fibrosis among } \\
\text { subjects consuming } \\
\text { wine }<70 \mathrm{~g} / \mathrm{w} \text {, and in } \\
\text { non-binge drinkers }\end{array}$ \\
\hline $\begin{array}{l}\text { Kimura et } \\
\text { al. } \\
2018[132]\end{array}$ & 301 & Liver biopsy & Cohort & $<140 \mathrm{~g} /$ week & $\begin{array}{l}\text { Clinical } \\
\text { interview }+ \\
\text { questionnaire }\end{array}$ & $\mathrm{HCC}$ & $\begin{array}{l}\text { Higher incidence of } \\
\text { HCC plus prevalence } \\
\text { of cirrhosis in } \\
\text { moderate consumers }\end{array}$ \\
\hline
\end{tabular}

Abbreviations: F0-4, fibrosis stage 0-4; HCC, hepatocellular carcinoma; NASH, non-alcoholic steatohepatitis; PEth, phosphatidylethanol. 